\title{
The semiotics of phonetic translation
}

\section{Igor Pilshchikov*}

\begin{abstract}
This article is devoted to translations of poetry that are not equivalent to the original on the lexical level, but attempt to reproduce the sound, rhythm and syntax of the source text. The Russian formalist Yuri Tynianov was presumably the first scholar to discover this phenomenon, which was later referred to as "phonetic facsimile" (George Steiner) and "homophonic translation" (Lawrence Venuti). The present discussion of the linguistic, semiotic and cultural aspects of (homo)phonetic translation is exemplified by translations made by Russian poets of the nineteenth and twentieth centuries.
\end{abstract}

Keywords: phonetic (homophonic, homophonetic) translation, equivalence in translation, sound in poetry, Russian poetic translations of the 19th and 20th centuries

\section{The problem of phonetic translation}

The prominent Russian scholar Mikhail Gasparov observed: "If a translation normally preserves the meaning, leaving no trace of the original sound, then why not allow a translation that preserves the sound but changes the original meaning?" (Gasparov 2006: 15). ${ }^{1}$ Gasparov cites as an example a poem by the "junior" futurist Semen Kirsanov titled "Osen" ("Autumn", 1925), which is, in fact, a "phonetic translation" (ibid.) of Paul Verlaine's celebrated "Chanson d'automne" ("Autumn Song", 1866):

* Author's address: Igor Pilshchikov, Tallinn University, School of Humanities, Uus-Sadama 5, 10120 Tallinn, Estonia, email: pilshch@tlu.ee.

1 Translations from languages other than English are mine unless otherwise stated. All emphasis in quotations is that of the original author. 
Osen'

Les sanglots longs... Paul Verlaine
Les sanglots longs

Des violons

De l'automne

Blessent mon cœur

D'une langueur

Monotone.

Tout suffocant

Et blême, quand

Sonne l'heure,

Je me souviens

Des jours anciens

Et je pleure. [...]

The contemporary Russian poet, translator and historian of poetic translation Evgeny Vitkovsky writes of Kirsanov that, with perhaps a few exceptions,

Russian poetry did not know such a virtuoso of wordplay or, to put it even better, of "word-games". Sometimes he even played in translation, rendering not the meaning of Verlaine's verses but rather their sound [...] A very interesting translator could have developed from such a poet, because the world is full of poems in whose translation the sound is more important than the meaning. But the epoch theorized otherwise and demanded either "an informative translation" or "a reproduction of a substitute for thought". (Vitkovsky 2004)

"Chanson d'automne" was indeed one of such poems "in whose translation the sound is more important than the meaning". This is testified by the Russian symbolist poet and verse theorist Valery Briusov, who was himself a translator of Verlaine. According to Briusov, much of the impression produced by such poems as "Chanson d’automne"

2 The transliterations of poems used in this paper distinguish between the vowels ë, ю and $я$ at the beginning of a word, after other vowels or after the soft $\operatorname{sign}(\ddot{e}=j o, ю=j u, ~ я=j a)$ and the same vowels after a consonant ( $\ddot{e}=\ddot{o}, ю=\ddot{u}, я=\ddot{a})$. 
should be ascribed to verbal music [muzyka slov], which can be imitated, but cannot be reproduced. [...] In these poems Verlaine remained faithful to the principle he had proclaimed: "De la musique avant toute chose". These are songs in which verbal music is brought to the foreground. In these short poems the verbal content is moved to the background, and we are first and foremost captivated by the sound of the words themselves, the combinations of the vowels, consonants, and nasals. (Briusov 1911: 9-11)

When we translate such poems, Briusov argued, we "should sacrifice fidelity to the image rather than the melodiousness of verse [pevuchest' stikha]" (ibid.: 11). Kirsanov seems to have followed this advice.

An obvious example of phonetic translation is found in the work of another Russian symbolist poet, novelist and verse theorist, Andrei Belyi - namely, in his novel Maski (Masks, 1932):

"[...] two years ago the widely known dwarf, Yasha, who was insane, settled in a corner of Selisvitsyn's apartment.

He was always standing on Sennaya Square with his hand outstretched.

In the evenings he sang German songs. People would have killed for such songs, but nobody held him responsible, a holy fool. Frol Murshilov, a mimic, modified the songs in his own particular way.

In Sünde und in den

Genuss gehn wir ab

Zum sinken, zum finden

Den traurigen Grab.

And Murshilov, at once:

Izümu da sin'ki

Za uzen'kij drap -

U Zinki, ufimki,

Tatarchenko: grab'!

- “Sing, Murshilov!” (Belyi 1932: 32-33; discussed in Lotman 2009)

The full text of this German song is found in Moskva pod udarom (Moscow in Jeopardy, 1926), the preceding novel in Belyi's so-called "Moscow cycle". Belyi provides the German text with a literal translation into Russian: "B грехе и в наслаждениях идем мы ко дну, чтобы найти печальную могилу” ['In sin and pleasures we are sinking to find the sad grave'] (Belyi 1926: 97 $\mathrm{ftn}$.). Murshilov's parody, if translated literally, reads grotesquely differently: 
"Raisins and blueing / for thick woolen cloth - / From Zinka, ${ }^{3}$ a native of Ufa, / Tatarchenko, ${ }^{4}$ steal!"

In the preface to Masks, Andrei Belyi describes the acoustic and rhythmic structure of his "Moscow" novels:

"[...] I do not write for reading with the eyes, but rather for the reader who pronounces my text inwardly, so I deliberately saturate the semantic abstraction not only with colours [...], but also with sounds [...], i. e. [...] I deliberately impose my voice by all means: with the sound of words and through the arrangement of the parts of the sentence. (Belyi 1932: 9-10)

This paper is therefore devoted to translations of poetry that are not equivalent to the source text on the lexical level, but attempt to reproduce the sound, rhythm and syntax of the original. According to J. C. Catford's Linguistic Theory of Translation, these levels are characterized by a certain "autonomy" and "detachability" or "separability for translation purposes" (Catford 1965: 11-13, 23). George Steiner called this phenomenon "phonetic facsimile" (Steiner 1998 [1975]: 427).

J. C. Catford noted that, in translations of poetry, we find "rare cases of deliberate attempts at partial replacement by equivalent TL [target language] phonology" (Catford 1965: $22 \mathrm{ftn}$., emphasis in the original). However, phonological theory teaches us that "there is no absolute correspondence (either materially acoustic or phonological) between the sounds of two different languages" (Fedorov 1928: 58). Therefore, it is impossible "to render the source text 'sound for sound," and, in the case of phonetic translation, the "target text is merely an approximation to the sound of the source text as filtered through the 'phonemic grid' of the target language" (Lefevere 1975: 20). Such an approximation, however, "works". Although two "similar" phonemes which belong to two different language systems cannot be "the same" element, their "physical resemblance", as Uriel Weinreich pointed out,

tempts the bilingual to identify the two phonemes astride the limits of the languages. Even syllables and whole words in two languages are occasionally equated by dint of their 'identical' or 'similar' phonemic shapes. (Weinreich 1953: 7, cf. 14-28) 
These words from Weinreich's classic study, Languages in Contact, helps us to understand the phenomenon of phonetic translation. When we speak of a similarity between phonemes, we sometimes do not assume any coincidence or similarity of their descriptions at the phonological level, but rather at the level of distinctive features (cf. Taranovsky 1965). Sometimes it is not an individual phoneme that is reproduced, but a particular distinctive feature or a cluster of features (cf. Pszczołowska 1977: 22-23; 1982: 390-391). This is the reason why the phenomenon under discussion should be defined as "phonetic" rather than "phonological" translation, contrary to Catford's definition (1965: 56-61). The search for proper terminology has not been confined to the opposition of "phonetic" versus "phonological" or "phonemic" (Lefevere 1975: 4-5, 19-26, 95-99). Lawrence Venuti, a leading contemporary historian and theorist of translation, has suggested the term "homophonic translation" (Venuti 2008 [1995]: 185-188; more on homophony and homonymy below, Section 7). Eugene Eoyang (2003: 154) named this phenomenon "translatophony".

On the other hand, the difference between phonological systems "can be ignored in cases where the compared phonemes are different in terms of their distinctive features, but there is no interfering element. For example, in the German language /t/ and /d/ are opposed as tense versus lax, while in French they are opposed as voiceless versus voiced, but, since there are no 'other' types of $t$ and $d$ in either language, these phonemes can be considered equivalent in these two systems" (Segal 1972: 59). As another member of Opoyaz, the linguist Evgeny Polivanov noted, "for interphonemic associations (which must be taken into consideration specifically with regard to the correspondences of non-identical sounds in poetic technique), only the acoustic side of the sounds compared may sometimes be essential - without correspondence in basic physiological aspects (in the position of the active organ of the given sound production)" (Polivanov 1974 [1930]: 356). It should be added that, in addition to phonetic equivalence, we are sometimes faced with graphophonetical or grapho-phonological equivalence (Pilshchikov 1991: 20). From this point of view, intertextual sound repetition is similar to intratextual forms of sound repetition, such as alliteration, which can also be partly based on graphic equivalence (see Lotman 1976: 63-64; Grigor'ev 1979: 264-265, 291294; Vekshin 2006: 40-50). A correlation between graphic forms is possible if some of the distinctive features are ignored and the difference between two phonemes is perceived as irrelevant (Brik 1917: 26-28; Skirmantas 1984: 8, 19). Czech verse theorist Miroslav Červenka even speaks of a "competition" between phonemes and graphemes (Červenka 2002: 14-16).

The same issue can be reformulated as the problem of interlinguistic interference in the situation of poetic bilingualism and its influence on the poet's 
individual criteria for translation accuracy (cf. Levinton 1979). In the Russian tradition of translation studies, a discussion of this type of correspondence between the source text (ST) and the target text (TT) was exemplified by translations made by the early romantic poet Vasily Zhukovsky (1783-1852), the late romantic poet Fedor Tiutchev (1803-1873), and the acmeist (post-symbolist) poet Osip Mandelshtam (1891-1938). The unusual nature of Tiutchev's translations was first revealed by the Russian formalist Yuri Tynianov, a member of the celebrated Opoyaz "triumvirate" (along with Shklovsky and Eikhenbaum) who may possibly be considered one of the first to discover "phonetic translation". His unfinished book on Tiutchev and Heinrich Heine was written between 1917 and 1922 but remained unpublished until 1977. Andrei Fedorov, a disciple of Tynianov and later a founder of Soviet translation studies, added more examples from Tiutchev and other Russian poet-translators in his article, "The acoustic form of poetic translations (The problems of metrics and phonetics)" (Fedorov 1928). Examples from Mandelshtam were discovered by Irina Semenko (1970). The Zhukovsky examples were analyzed by the author of the present article (Pilshchikov 1991). It is interesting to note that in many other aspects of poetics, Zhukovsky was a predecessor of Tiutchev, and Tiutchev - a forerunner of Mandelshtam. ${ }^{5}$

\section{Russian poets and critics on sound in verse}

Many Russian poets and critics - the romantics in the nineteenth century, the modernists and avant-gardists in the twentieth - insisted on the priority of sound in verse in relation to meaning.

In his article "Slovo i kul'tura" ("The Word and Culture", 1922) Osip Mandelshtam wrote:

The poem lives through an inner image, that ringing mold of form that anticipates the written poem. There is not yet a single word, but the poem can already be heard. This is the sound of an inner image; this is the poet's ear touching it. (1979: 116)

\footnotetext{
5 Ironically, the surname of the author of the "phonemic translations" of Catullus analyzed by Lefevere (1975), the American poet Louis Zukofsky (1904-1978), the son of immigrant Russian Jews, is nearly homophonic with the surname of the originator of this type of translation in Russian literature, Vasily Zhukovsky (1783-1852). On Louis Zukofsky's Catullus as an example of "modernist experimentalism in translation" (Venuti 2008 [1995]: 186) see also Raffel 1988: 23-28; Hooley 1988: 55-69.
} 
The symbolist Viacheslav Ivanov, Mandelshtam's first mentor in poetry, discussed the same problem in his essay "K probleme zvukoobraza u Pushkina" ("On the Problem of the Sound-Image in Pushkin", 1925). He emphasized the attention that romantics and early symbolists paid to this stage in the genesis of the poetic text:

Musical-rhythmic excitation [...]; the auditory captivation [...] that attracts the sound-composer to obscure glossolalia [...]; and, finally, the dream-like experience of the dynamic rhythm-image [ritmoobraz] and of a more stable sound-image [zvukoobraz], an experience which gravitates toward the arrangement and comprehension of the object of contemplation [...] - these are the easily distinguishable and coequally powerful elements of that living unity of forces which come to life sequentially and which work in concert that we typically experience in the act of poetic creation.

Homing in on this act at its inception would provide snapshots of pure glossolalia [...]. This articulate, but wordless sound-speech [zvukorech'], is connected to a particular language by a common phonetic structure. It struggles to give birth in the sphere of language to a word as a symbol of a "transrational" image - a first, completely murky representation which seeks to crystallize from emotional agitation. The fact that poetic creation commences from the formation of these blurry spots, is evidence that poetry is truly a "function of language" and a manifestation of its organic life [...].

If a poet cannot or purposefully avoids bringing the poetic act to its full conclusion, his work preserves the imprint of one of these steps in the process, where elements of the initial sound-composition are incompletely illuminated through image and sense, where the direct mutual attraction of homonyms turns out to be stronger than the configurative instruments of artistic imagination and apprehension. The romantics and the early symbolists had areat fondness for this stage of fluid and flexible images glimmering vaguely in the surge of sounds because it retains something of the original uncontrolled impulse, in which they saw proof of true "inspiration". (Ivanov 1930 [1925]: 95-96)

Although his essay contains a polemical message that argues against the ideas of the Russian formalists (Etkind 1994: 148-151), Ivanov nevertheless agreed with his opponents in their interpretation of the role of "trans-sense" in the genesis of poetic texts. 
Viktor Shklovsky and Lev Yakubinsky, contributors to the first collection of formalist essays published in 1916 (devoted in its entirety to the role of sounds in poetic language), declared:

$[\ldots]$ very often [...] verses emerge in the poet's soul in the form of acoustic spots, which are not yet cast in words. The stain now approaches, now moves away, but eventually brightens and coincides with an assonant word. [...]

One may perhaps similarly interpret the confessions of poets in which they say that verses emerge (Schiller) or ripen in their soul in the form of music. I think these poets fell victim to a lack of precise terminology. There is no word for inner sound-speech [zvukorech'], and when they want to say something about it, the term "music" turns up as a description of certain sounds which are not words. In this particular case they are not yet words because they eventually take a verbal shape. [...]

Perceptions of the poem are usually also reduced to a perception of its acoustic prototype [pra-obraz]. (Shklovsky 1916: 10, "On Poetry and Transrational Language")

In [the mind of] poets with auditory imagination, perception of the movements of the speech organs can evoke corresponding auditory (or acoustic) representations, and then the selection of sounds for the poem takes place on the basis of these auditory representations. In this case, the series of movements of the speech organs or the series of auditory representations constitutes the starting point for poetic linguistic thought. It is in this sense that we should interpret an avowal made by many poets concerning sounds as the initial point of poetic creativity. (Yakubinsky 1916: 29, "On the Sounds of Poetic Language"; emphasis in the original)

Later, in his unfinished book Rhythm and Syntax, Osip Brik claimed that "according to recent observations, poetic work develops" as follows:

In the beginning, the poet gets a vague representation of a certain lyric complex, of a certain acoustic and rhythmic structure, and only then is this transrational structure filled with meaningful words. Andrei Belyi wrote about this, Blok spoke about this, and the futurists also spoke of this. (Brik 1927, 6: 35)

Blok's experience was corroborated by Shklovsky:

Very often a line of a poem emerges in the artist's mind in the form of a certain acoustic spot, which is not yet clarified into words. The words come as a motivation for sounds. A. A. Blok told me about such a phenomenon on the basis of introspection. (Shklovsky 1923: 10) 
The futurist who "also spoke" of this phenomenon was Vladimir Mayakovsky, a leading poet of the Russian avant-garde, who wrote about the fundamental "rumble-rhythm" or "rhythm-din" [gul-ritm] in his article "Kak delat' stikhi?" ("How to Make Verse", 1926). ${ }^{6}$ This basic rumble/din/rhythm comes first, when "there are almost no words yet", and only "gradually is one able to make out single words in this din" (cf. Timofeev 1958: 83-84). Having quoted this evidence, Krystyna Pomorska concludes that for Blok and Mayakovsky, who were "otherwise so different", "rhythm was primordial and the word secondary" (Jakobson, Pomorska 1985: 22). Not only rhythm, we might add, but also sound.

The main difference here is not between modernist and avant-gardist practices or between symbolist and formalist theories, but between a psychological (causal) and a functional (teleological) interpretation of the phenomenon under discussion. In this frame of reference, there is one formalist critic who dissents from all other formalists and the symbolist Ivanov. This critic is Boris Eikhenbaum. Initially he also supported a generative psychological explanation of the priority of sound in poetry:

It is possible to imagine that a poet may have an articulatory design [proiznositel'nyj zamysel] (the inner mimics of the speech organs) that is not connected with ready-made words. Then, the process of fighting with the word should take place, and the poem can be considered a kind of compromise between a pure design and the nature of the material. (Eikhenbaum 1987 [1918]: 335, "On the Artistic Word")

However, Eikhenbaum later offered an anti-psychological interpretation of the same phenomenon:

The organizing principle of lyric poetry is not the ready-made word, but an intricate complex of rhythm and verbal acoustics, often with the predominance of some elements over the others. This complex is, in the logical sense, the first stage in the realization of abstract artistic concepts. In this sense, the sounds of verse (their speech representations, both acoustic and articulatory) are self-valuable and self-signifying. (Eikhenbaum 1924 [1920]: 206, "On Sounds in Poetry"; emphasis in the original)

$6 \quad$ For the English translation see Mayakovsky 1975 [1926]. 
For Eikhenbaum, sound in poetry plays a constructive role, "whatever the real psychological genesis" of the poem may have been (Eikhenbaum 1924 [1921]: 206).

To describe this constructive factor, a new term was invented: "The sum total of all of the means of acoustic organization of verse is commonly called instrumentation" (Shtokmar 1939: 803). The terms 'verbal instrumentation' (slovesnaia instrumentovka) and 'phon(et)ic instrumentation' (zvukovaia instrumentovka) or simply 'instrumentation' (instrumentovka; also translated as 'orchestration') derives from René Ghil's instrumentation verbale (see Wellek, Warren 1963: 294-295, note 2; Kviatkovsky 1966: 122). They were introduced into Russian literary theory by the symbolists Valery Briusov (1904: 26-29) ${ }^{7}$ and Andrei Belyi (1910), ${ }^{8}$ and then reinterpreted by the formalists, first and foremost by Brik in his article "Sound Repetitions" (1917: 26) and Eikhenbaum in his articles of 1921 and 1922.9 Tynianov spoke of "verse instrumentation" and "acoustic instrumentation" in a series of articles written from 1920 to 1922 but published later (in two cases, considerably later) than Eikhenbaum's. ${ }^{10}$

As distinct from Andrei Belyi, the formalists and their disciples developed a functional interpretation of instrumentovka. To summarize their position in a few quotations, we can "speak of 'instrumentation', of acoustic organization, of the value of sound itself [...] only if there is an orientation [ustanovka] toward an acoustic factor, if the organization of the acoustic qualities within certain units and entities is designed and perceived as a structural fact" (Fedorov 1928: 57), i. e. if "the qualitative aspect of sounds in speech" acquires "the significance of the constructive factor of the literary whole" (Bernshtein 1929: 184). An entry in Eikhenbaum's diary dated 18 June 1921 describes his conversation with Tynianov about "preparing a collection of essays on instrumentation" (such a collection was never published). Eikhenbaum writes: "I have been thinking about this recently. It is necessary to distinguish between the articulatory and acoustic phenomena. In contrast to linguistics, in both cases it is

\footnotetext{
7 Briusov interpreted Ghil's theory of "instrumentation verbale" as an empirical justification of Verlaine's slogan, "De la musique avant toute chose". See Roman Doubrovkine's comment on Briusov's letter to Ghil of 13/26 April 1904 (Doubrovkine 2005: 89-91).

8 On verbal instrumentation as an "arrangement and combination of words" see Belyi 1910: 232-233; on acoustic instrumentation see Belyi 1910: 251, 283-284, 391, 410-417 et al.

9 See Eikhenbaum 1924a [1921]: 201; 1924b [1921]: 213; 1922: 9-10; cf. Mandelker 1983: 328,330 .

10 See Tynianov 1977 [1922]: 385-387, 393; 1977 [1921-22]: 54 ftn., 55, 77 ftn.; 1929 [1922]:

72. See also Tynianov 1924: 100-108, cf. 35, 128-129, note 37.
} 
necessary to consider the moments of artistic significance". ${ }^{11}$ Thus, the concept of 'instrumentation' / 'orchestration' is broader than the traditional notion of 'euphony' because it signifies any functional organization of sound and not only pleasant, agreeable sound implied by the prefix eu- (cf. Wellek, Warren 1963: 159). In the case of phonetic translation, instrumentation in the TT may have two different functions: either to create an acoustic effect which is the same as (or similar to) the phonetic structure of the ST (dynamic or functional equivalence) or to reproduce the phonetic structure of the ST (formal equivalence). ${ }^{12}$

Why should the poet-translator imitate the phonetic structure of the original if it cannot be interpreted as onomatopoeia, alliteration or any other type of semanticized or purely formal euphony? A possible answer is that sound, which is directly linked to the deep layer of signification, is often more important to the poet than the literal meanings of words. More than eighty years before the symbolists and futurists, the Russian romantic critic Nikolai Polevoy claimed the same, referring to Zhukovsky:

That which made him unique among all other poets - a harmonious language so to speak, the music of the language, is imprinted in Zhukovsky's poems [...] He polishes every note of his song carefully and accurately, he cherishes the sound as well as the word [...] Zhukovsky plays the harp: enduring modulations of sounds precede his words, which are sung by the poet only to explain what he wants to express with sounds. (Polevoy 1839: 115, 123; quoted by Eikhenbaum [1922: 29-30] and Tynianov [1924: 82-83])

This definition ("modulations of sounds precede his words") describes Zhukovsky's translation techniques surprisingly well.

\section{Zhukovsky's translation techniques}

For contemporary as well as later critics, Vasily Zhukovsky was one the founders of a new school in Russian poetry (which we tend to define as pre-romantic or early romantic) and an immediate predecessor of Russia's greatest poet,

11 Quoted in http://nikita-spv.livejournal.com/11168.html (accessed 30.04.2016). The manuscript is kept at the Russian State Archive of Literature and Art (RGALI), fond 1527, opis' 1, ed. khr. 244. See also Wellek, Warren 1963: 146-147; Kolarov 1983: 20-22.

12 On dynamic equivalence as opposed to formal equivalence see Nida 1964: 166-177. 
Aleksandr Pushkin. An essential characteristic of Zhukovsky's poetry is the abundance of translations in his oeuvre. More than half of his poems are translations or imitations of French, English and, most importantly, German poetry. In the history of Russian literature, Zhukovsky is considered the first poet-translator and a poet-translator par excellence.

The critics' judgments concerning Zhukovsky's translation practices are not unanimous. On the one hand, we observe the poet-translator's careless attitude to the originals, which for him, in the words of leading Russian comparatist Yuri D. Levin, "were sometimes only a pretext to express his own emotions" (Levin 1972: 231; see also Levin 1985: 15; Durišin 1979: 165; Shveitser 1988: 173-176). On the other hand, in the opinion of another authoritative Russian scholar, Sergei Averintsev, we find not only "semantic and artistic fidelity, but also very simple, literal and 'literalist' fidelity at different levels" of Zhukovsky's translations (Averintsev 1988: 256).

In a normal situation the translator, in search of equivalents, is constantly shifting from one level to another (Catford 1965: 24-25, 73-82). The high frequency of such inter-level transitions within the same text is fundamental to Zhukovsky's art of translation. An adequate assessment of Zhukovsky's translation techniques requires an examination of the segments of the TT that do not set up formal equivalence to the ST on the lexical level. ${ }^{13}$ Given that translation in the romantic era did not have a purely informative function, the translator retained the right of subjective arbitrariness in choosing text equivalents (see Levin 1963: 19-23; 1972: 222-240; 1985: 8-21).

Let us begin with onomastics. "Zhukovsky's refined sensitivity to the acoustic substance of foreign names", noted by Averintsev (1988: 263), manifests itself in the poet-translator's specific attitude toward anthroponyms, place names and other proper nouns. The clausula (ending) of a verse line is a segment that is rhymed metrically and, in rhymed verse, phonetically. An eloquent detail: if a proper name that occupies the clausula in the original is not replaced with a different name in Zhukovsky's translation, it almost always also occupies the clausula (cf. Fedorov 1928: 63-64). In some cases the motivation is clearly phonetic, as in his translation (1809) of Schiller's "Kassandra" (1802):

I Sélig préis' ich Polyxénen

${ }_{2}$ In des Hérzens trúnknem Wáhn,

${ }_{3}$ Dénn den bésten der Hellénen

${ }_{4}$ Hófft sie brấutlich zu umfáhn.
I' Sládkij zhrébij Poliksény!

${ }_{2}^{\prime}$ S zhenikhóm ruká s rukój,

3'Vzór, lübóv'ju raspalénnyj,

4'I gordấs’ samá sobój [...]

13 On formal equivalence see Nida 1964: 159-160, 165-166; Catford 1965: 32-34. 
The third and the fourth lines of the ST quatrain have no lexical equivalents in the TT, ${ }^{14}$ but at the same time the interlinguistic (i. e. intertextual) rhyme "ST-3 : TT-3"' proves to be richer than the intratextual rhyme "TT-1': TT-3'”: in ST line 3 and TT line $3^{\prime}$, the rhymed ictus contains the onset consonant [1] ([-'le:nən] in $3 \rightarrow$ [-' ljen:əi] in $\left.3{ }^{\prime}\right) .{ }^{15}$ Moreover, the penultimate foot in both lines 3 and 3 ' contains a rhotic consonant (der and $\underline{r}$ as-). Although these sounds have different articulation in German and Russian (and may even have different variations in German), both versions of / $\mathrm{r} /$ can be categorized as a sonorant trill. The odd lines in the ST $(1 \& 3)$ and the TT $\left(1^{\prime} \& 3^{\prime}\right)$ are rhythmically identical: the trochaic tetrameters with feminine endings are split into two equal hemistichs ( 2 feet + 2 feet $=4$ syllables +4 syllables). It is noteworthy that the onset consonants of the second feet in the ST lines ( $p[$ в] eis'ich in line 1 and den [b]esten in line 3 ) are also reproduced in the TT (zh[r]ebij in line 1' and lï[b]ov'ju in line $\left.3^{\prime}\right)$. The cor-

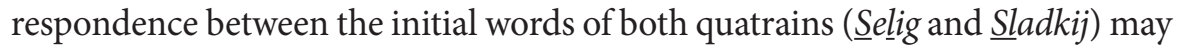
be qualified as grapho-phonological. Moreover, the ST repetition [-Iç ... -Iç] (in Selig preis'ich) is echoed as Sladkij zhrebij in the TT. Thus, two disyllabic words in the first hemistichs of both the ST and TT are visually and acoustically "similar", and precede the name of Polyxena, which occupies the second hemistich.

In Zhukovsky's translation (1812) of Friedrich von Matthisson's "Elysium" (1787), the key name Anadyomene occupies three feet of the trochaic tetrameter with a masculine ending, that is, the entire line except for the monosyllabic clausula. Zhukovsky reproduced not only the name itself (and the sound of the name!), but also the sound of the clausula:

${ }_{1}$ Só in héil'ger Stílle rúhten ${ }_{2}$ Lúft und Wógen, álso ${ }^{16}$ schwíeg ${ }_{3}$ Die Natúr, $\mathrm{da}^{17}$ aus den Flúten ${ }_{4}$ Anadyoméne stíeg.
I'Ták molchálo vsố tvorén’je -

2'Móre, vózdukh, béreg dík, -

3'Zrắ penístykh vód rozhdén’je,

4' Anadiomény lík.

The last line in the ST means 'Anadyomene stood (up)'; the corresponding line in the TT means 'Anadyomene's face'. However, the monosyllabic verb stíeg [ [ti:k] ('stood') sounds very similar to the monosyllabic noun lik [lijk]

14 The literal meaning of the German text ('...because to the best of the Hellenes / she hopes to give a bride's embrace') has nothing to do with the Russian translation ('her eyes [are] inflamed by love / and, proud of herself...). The vocabulary and phraseology of Zhukovsky's line 3' (Vzor ljubov'ju raspalennyj) derive from Gavriil Derzhavin's anacreontic poem, "K pervomu sosedu" (“To My First Neighbour", 1780): ...ljubov'ju raspalennyj strastnoj... ('inflamed by ardent love').

15 In Russian the vowels of the stressed syllables are normally longer than the unstressed vowels, but this difference has no phonological significance.

16 Matthisson 1789: 108. A variant in later editions: so nur.

17 For the comparison of two adaptations see Ďurišin 1976: 496-498. 
('face'): the syllabic core of both monosyllables (the nucleus vowel and the final consonant, or coda) fully coincide. The same applies to the monosyllables [Jvi:k] ('kept silence') in "álso schwíeg" and [dik] ('wild, savage') in "béreg dík" ('the wild shore'). The ST rhyme "[-i:k] : [-i:k]" (ST-2: ST-4) is thus faithfully copied in "TT-2" : TT-4", but the phonetic correspondences are not limited to the sounds in the clausulae. The phonetic structure of the ST is reproduced not only in the fourth line, but also in the second line of the TT, in which the stressed syllable of the second foot [vo(:)-] is preserved. The ST hemistich Lúft und Wógen means 'air and waves', whereas the corresponding hemistich in the TT (Móre, vózdukh) means 'sea [and] air'. The noun vózdukh ('air') correlates both metrically and phonetically with the noun Wógen ('waves') and corresponds semantically to the noun Luft ('air').

What is said above about proper names can be also applied to international vocabulary. For example, Zhukovsky's translation of Schiller's "Berglied" ("Song of the Mountain", 1804), published in 1818 as "Gornaja pesn"” ("Song of the Mountain") and then renamed as "Gornaja doroga" ("The Mountain Road"), features the rhyme "trone : korone" which corresponds to the rhyme "Throne: Krone" in the German original.

An interesting example is found in Zhukovsky's translation of Gottfried August Bürger's "Lenore" (1773), published in 1831 under the eponymous title "Lenora". In this version, Zhukovsky attempted to convey the text of Bürger's celebrated ballad more precisely than he did in his earlier imitation of the same poem, titled "Ljudmila" (1808). ${ }^{18}$ The German noun Chor and the Russian noun khor, both meaning 'choir', are both placed in the clausula:

Kómm, Kǘster, híer! Kómm mit dem Chór Za mnój, pevtsý, za mnój, pastór;

Und gúrgle mit des Bráutlìed vòr! ${ }^{19}$ Propój nam mnogolét’je, khór [...]

This is not sheer coincidence. A comparable example is found in the first stanza of Zhukovsky's "Prizvanie" ("Calling"), an adaptation of A. H. von Weyrauch's song "Der Jünger" ("The Disciple", 1809). ${ }^{20}$ Here the rhyme

18 For the comparison of two adaptations see Duurišin 1976: 496-498.

19 Here et passim, grave accents denote secondary stresses.

20 The Russian version remained unpublished during the translator's lifetime. August Heinrich von Weyrauch (or Weirauch, 1788-1865) was a locally-known Baltic German composer and songwriter, Zhukovsky's acquaintance in Dorpat (Tartu). On Weyrauch see Gottzmann, Hörner 2007: 1402-1404. 
“Chor ('choir') : Tor ('gate')" is rendered as " $<$ Snät' il' net s dverej> zatvór ('<To undo or not to undo $>$ the bolt < of the door $>$ ') : khor ('choir')", ${ }^{21}$

The words in the TT that form an intertextual rhyme and thus establish a phonetic equivalence with the ST may be not at all correlated at the morphemic or lexical levels. More examples from "Lenora":

Rásch auf ein éisern Gíttertòr [...] K vorótam kón’ vo vés’ opór [...]

Mit schwánker Gért ein Schlág davór [...] Ezdók bichóm stegnúl zatvór [... $]^{22}$

Was hálf, was hálf mèin Béten? $\quad$ Pred ním mòj krík bỳl tshchéten...

Nún íst's nicht méhr vonnốten. Oòn glúkh i bezotvéten.

This type of interlinguistic/intertextual rhyme in Zhukovsky was first identified by Andrei Fedorov. The rhyme “[-ax] : [-ax]” in Mignon's song from Goethe's novel Wilhelm Meisters Lehrjahre (1795):

Kénnst du das Háus? Auf Sä́ulen rúht sein Dách,

Es glä́nzt der Sáal, es schímmert das Gemách -

is reproduced in Zhukovsky's translation (1817):

Tám svétlyj dóm! Na mrámornykh stolbákh

Postávlen svód; chertóg gorít v luchákh.

Tiutchev later copied the same rhyme in his translation of Mignon's song (1851), following Zhukovsky (see Fedorov 1928: 62-63):

Ty znáesh' dóm na mrámornykh stolpákh?

Sijáet zál i kúpol vés' v luchákh.

In Zhukovsky's translation of Goethe's "An den Mond" (second version, 1789), titled accordingly "K mesjatsu" (“To the Moon", $1817^{1}, 1824^{2}$ ), the phonetic echoes of the original in stanzas 4 and 6 are clearly of an onomatopoeic nature:

21 This example was reported to me by Andrei Dobritsyn. It is not, however, analyzed by Eichstädt (1970: 43-46), who examined the phonetic structure of "Prizvanie".

22 Here, just as in "Prizvanie", zatvor ('bolt') corresponds phonetically to the German $<$ Glitter $>$ tor ('<lattice->gate'), while the latter also finds a formal lexical equivalent in the TT: vorota ('gate'). 
(4) Léjsä, mój ruchéj, stremís’! Zhízn' uzh ottsvelá;

Ták nadézhdy proneslís';

Ták lübóv’ ushlá.

[...]

(6) Léjsä, léjsä, mój ruchéj, I zhurchán’je strúj [...]
(4) Flíeße, flíeße, líeber Flúß !

Nímmer wírd' ich fróh [...]

(6) Ráusche, Flúß, das Tál entláng,

Ohne Rást und Rúh [...]

The initial version of the first line of stanza 4 in the TT reads: Léjsä, mój ruchéj, nesis'! (Zhukovsky 1818: 31). Apparently, the translator substituted the imperative nesis' ('rush') with its synonym, stremis' ('rush'), for purely stylistic reasons: it rhymed with another word of the same root (proneslís'). At the same time both redactions of the TT preserve the interlinguistic consonance

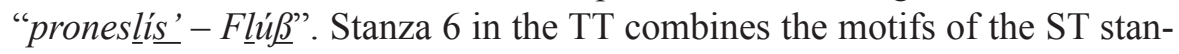
zas 6 and 4. This fact remained unnoticed by influential paraformalist critic Viktor Zhirmunsky, who wrote about the "modified acoustic instrumentation" [izmenennaja zvukovaja instrumentovka] in stanza 6 of the TT as compared to the ST (Zhirmunsky 1932: 544; 1937: 108). ${ }^{23}$

The instrumentation of Zhukovsky's translation of Goethe's "Der Fischer" (1778), made a few months after the translation of "An den Mond", has also attracted the attention of the scholars. The second stanza describes a mermaid coming out of the water:

1 Sie sáng zu íhm, sie sprách zu íhm:

"Was lóckst du méine Brút

${ }_{3}$ Mit Ménschenwìtz und Ménschenlìst

4
${ }_{1}$ Glädít onà, pojót onà:

“Zachém ty mój naród

3' Manáish', vlechốsh's s rodnógo dná

4' V kipúchij zhár iz vód?”

"The musical pattern of Goethe's poem is more modest, more obtuse", as one respectable historian of Russian poetic translation maintains (Etkind 1973: 84). However, a significant part of the ST pattern is reproduced quite faithfully in the TT. In the second line, the phrase " $<$ Was lockst $>[\mathrm{d}] u[\mathrm{~m}][\mathrm{ai}][\mathrm{n}] e$ $B[$ в $]$ ú $\mathrm{t}]$ ("<Why do you lure $>$ my brood')" is semantically, rhythmically and phonetically copied as " $<$ Zachem $>$ [t]y [m] [oi] [n]a[r]ó[t] / $<$ Manish' $>$ ( $<$ Why do you lure $>$ my people')", with rounded vowels /u/ and /o/ in the clausula.

23 Kahlenborn (1985: 152) repeated Zhirmunsky's opinion without any reference to Zhirmunsky. For the analysis of the imagery in Zhukovsky's translation in comparison with Goethe's original, see Semenko 1975: 89-90; 1976: 49-50. 
The verb manish' in the third line of the TT corresponds semantically to lockst the second line of the ST, and phonetically to Mensh-in the third line of the ST. At the same time, the onomatopoeic consonant pattern in the third line of the ST ("[m] it [m]é[nf]en-[v]itz und [m]é[nf]en-[1]ist") is partly imitated in the TT as " $[\mathrm{m}] a[\mathrm{n}] \hat{\imath}\left[\int\right],[\mathrm{v}]\left[\mathrm{l}^{\mathrm{j}}\right] e[\mathrm{t}] \ddot{\partial}\left[\int\right]$ s ro[dn]ógo $[\mathrm{dn}] a ́$ ", with no semantic correspondence between $\mathrm{TT}$ and $\mathrm{ST}^{24}$

Another example of onomatopoeia in both TT and ST is Zhukovsky's translation of Schiller's "Der Taucher" (“The Diver", 1797), titled "Kubok" (“The Goblet", 1831). I refer to the first line of the sixth and twelfth stanzas, which Goethe praised in his letter to Schiller on 25 September 1797:

I had almost forgotten to tell you that the verse, "It bubbles, it hisses, and rushes and roars" [Es wallet und siedet und brauset und zischt], \&c., is perfectly justified at the falls of Schaffhausen [bei dem Rheinfall]; it was to me remarkable how it embraces the chief moments of the prodigious scene. (Schiller, Goethe 1845: 339; 1870: 372)

"In the centre of Schiller's poem is a raging sea painted with the intensive use of verbal sounds", Efim Etkind explains. "This is probably one of the best images of sea waters in world literature" (Etkind 1973: 87-88). According to this scholar, Schiller's "sound painting" in "Der Taucher" has a "consistently iconic character", especially when it comes to the [v]/[f] and [f] alliterations (ibid.: 88), but Zhukovsky's "musical imagery is even more intense and profound" (ibid.: 89). On the other hand, there are segments in Zhukovsky's translation that can be described as a "phonetic facsimile" of the German original. Such is Zhukovsky's rendition of Schiller's line so admired by Goethe:

Und es wállet und síedet und bráuset und zíscht

I vójet, i svíshchet, i b jót, i shipít

All four verbs in the ST and TT are in the 3rd person singular, ending in [-t]. This parallelism is supported by the similarity between the onset consonants in the stressed syllables of the first three verbs $\left([\mathrm{v}]-[\mathrm{z}]-[\mathrm{b}]\right.$ in ST, $[\mathrm{v}]-\left[\mathrm{s}^{\mathrm{j}}\right]-\left[\mathrm{b}^{\mathrm{j}}\right]$ in TT), the stressed $[\mathrm{i}(:)]$ in the second and fourth ictuses (i. e. at the end of

24 'With [your] human wit and human cunning' (ST) vs. '[You] lure [and] tempt [us] from [our] native seabed' (TT). 
the first and second hemistichs), and the onomatopoeic [ [] in the last verbs in the ST and TT. ${ }^{25}$

Last but not least, formal phonetic equivalence between the TT and ST may have no onomatopoeic motivation - in this case, it becomes a neat example of "phonetic facsimile". In this regard, one may note the phonetic translation of forms of address in Zhukovsky's "Lenora". A century ago the critic Vasily Kaplinsky was surprised that "Lenora always addresses her mother as 'friend' [drug]" (Kaplinsky 1915: 19). It is strange indeed if we ignore the fact that it is not semantics, but the instrumentation of forms of address in the ST ( $O$ Mútter, Mútter) and the TT ( $O$ drúg moj, drúg moj) that are similar:

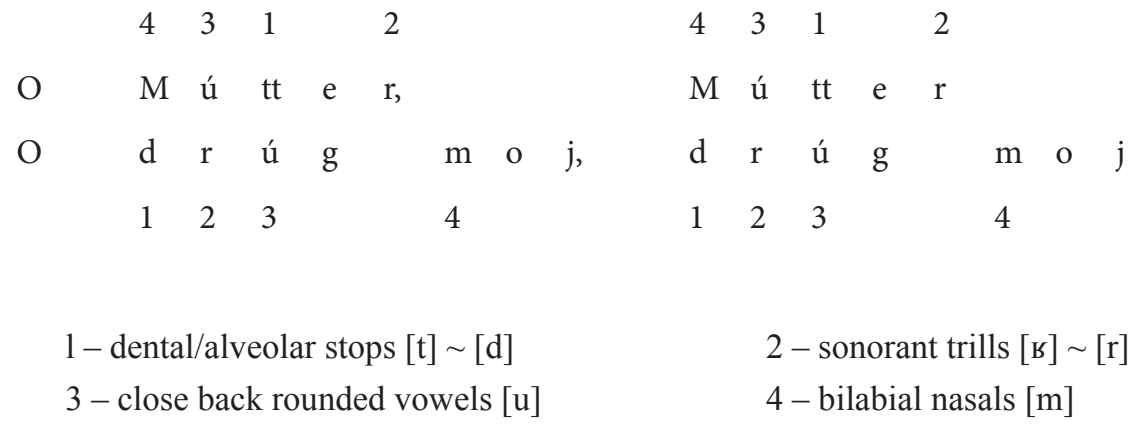

Moreover, the Russian and the German lines have the same rhythmic-accentual and word-boundary structure (more on this below). Characteristically, in Zhukovsky's "Lenora" the German Mutter ('mother') in the narrator's speech is always conveyed as mat' ('mother'). The appellative drug ('friend') appears in a few other fragments of the TT without being the lexical-semantic equivalent of any word in the ST. In one instance, however, the phonetic allusions to the ST are recognizable: [...] Und frúg nach allen Námen [...] I drúga vyzyváet. ${ }^{26}$

\footnotetext{
25 Compare a pre-Zhukovskian translation of this line, in which the onomatopoeic effect is absent: "I more bushujet, klubitsä, stekajet" (Pokrovsky 1820: 84, 85). It is known that in December 1819 Ivan Pokrovsky (1800-1863) read his translation aloud in the presence of Zhukovsky (Kotomin 2007: 25). Interestingly enough, Zhukovsky started working on his own version of "Der Taucher" much earlier, in April 1818, but stopped after the fifth stanza, and returned to this translation as late as 1831 (Lebedeva 2008: 395-397).
}

26 'And [she] asks for all names' (ST); 'And [she] calls for a friend' (TT). 


\section{Tiutchev's translation techniques}

Fedor Tiutchev was considered a second-rate poet by his contemporaries, but the critics of the modernist era drastically re-evaluated his legacy so that he is now commonly assessed as one of the three greatest Russian poets of the nineteenth century along with Pushkin and Lermontov. Tiutchev was deeply immersed in German culture, and his translations from German are of special interest.

Examples of phonetic translation in Tiutchev, as already stated above, were analyzed by Yuri Tynianov and Andrei Fedorov. Tynianov, in particular, studied the phonetics of Tiutchev's translation (1827-1829) of Heinrich Heine's poem, "Wie der Mond sich leuchtend dränget..." (1824). Tynianov was stunned by the fact that, in Tiutchev's poem,

the instrumentation is evidently preserved [...] intentionally and consciously: the first line of the fourth stanza in Heine's poem:

\section{Lauten klangen, Buben sangen}

is translated by Tiutchev as:

Deti peli, $v$ bubny bili.

Here we have a reproduction of the internal rhyme, "klangen - sangen" [...] as "peli - bili"; a particular word, "Buben" ['boys'], is reproduced with evident harm to the transmission of meaning, as the [phonetically] identical "bubny" ['tambourines']. (Tynianov 1977 [1922]: 385) ${ }^{27}$

Andrei Fedorov arrived at the same conclusions as Tynianov (see Fedorov 1928: 62). However, he added a special note to his analysis of the line "Deti peli, v bubny bili": "I owe my gratitude to S[ergei] I[gnat'evich] Bernshtein for providing me with this example" (ibid.: 68, note 17). A few questions arise here that will have to remain unanswered for the time being. Was Bernshtein acquainted with Tynianov's then-unpublished study? Why did Fedorov not learn this cornerstone example from Tynianov, who supervised Fedorov's graduate thesis "Heine in Russian" (Fedorov 1929 [1927]) at the Faculty of Letters of the Higher State Courses in Art Criticism at the State Institute of the History of Arts? (cf. Fedorov 1983 [1974]: 85-91, 100-101). In his memoirs,

\footnotetext{
27 Nikolai Sharov, who studied Tiutchev's translations from Heine at the same time as Tynianov and found in them "more than thirty textual deviations from the original" (Sharov 1922, 2/3: 98-99), also analyzed the lines in question, but noticed only the lexical and stylistic inadequacy of the translation (ibid.: 109).
} 
Fedorov remarked that he (to quote) had "used the advice of Yuri Nikolaevich [Tynianov] and my other mentor, Sergei Ignat'evich Bernshtein, - with precise notes acknowledging their help - as early as 1927-29, in my first published works" (ibid.: 91). Is it not possible that the observation which proved to be crucial for the topic under discussion actually belonged to Bernshtein, while Tynianov simply did not have time to add a citation crediting his colleague in his unfinished monograph? Finally, the same classic example (without any mention of Fedorov's article) is cited in the articles on Tiutchev and Heine published a few decades later by Alfred Kerndl (1956: 296) and Igor' Vakhros (1966/1967: 434).

It is worth noting that the word búbny ('tambourines') corresponds, both metrically and phonetically, to the word Búben ('boys'), and correlates semantically with the word Lauten ('lutes'). This example of double correlation ("split reference") can thus be compared with the analogous examples from Zhukovsky, when one word in the TT corresponds at different levels to

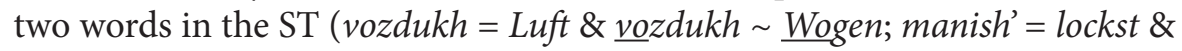
$\underline{\text { maninh }} \underline{\text { i }} \sim \underline{\text { Mensh }}$-).

Similarly to Zhukovsky, Tiutchev often preserved international lexemes in his translations and, whenever possible, kept them in the same metrical position as they were in the original. Tynianov (1977 [1922]: 386) found the following example in Tiutchev's translation (1829) of Heine's "Liebste, sollst mir heute sagen..." (1822):

Basilísken und Vampíre [...]

Vasilíski i vampíry [...]

In Tiutchev's translation (1827-1830) of Goethe's "Hegire" (from West-östlicher Divan, 1814-1819), not only are the words Nord (Russian Nord) and Throne (Russian Trony) preserved, but the instrumentation of the second hemistich of the first line and the entire second line is also copied quite faithfully:

Nórd und Wést und Súd zersplíttern, Západ, Júg i Nórd v knushén’’je, ${ }^{28}$ Thróne bérsten, Réiche zíttern [...] Tróny, tsárstva v razzrushén’je [...]

28 This is the text of the initial version of the translation; Tiutchev soon changed the order of the cardinal points: Západ, Nórd i Júg v krushén’je [...] (see Tiutchev 1966: 67, 285). The German Süd ('South') is translated as Jug ('South'), and has the same consonant in the coda as Nord ('North'). The standard Russian word for 'North' is Sever, but the poet chose to use a loanword to keep closer to (the sound of) the German original. 
Tiutchev's translation (1830) of Heine's “Das Herz ist mir bedrückt, und sehnlich..." (1824) begins with a perfect rhythmical-syntactic rendition of the first line (“Zakrálas' v sérdtse grúst' - i smútno...") and continues with accurate phonetic touches at the end of the second and fourth lines and at the beginning of the third line of the second stanza:

Dóch jétzt ist álles wie verschóben, ${ }_{2}$ Dàs íst ein Drä́ngen! eine Nóth! 3 Gestórben ìst der Hérrgòtt óben, ${ }_{4}$ Und únten ìst der Téufel tódt.
1'A nýnche mír vès' kak raspálsä:

2, Vsồ kvérchu dnóm, vsè sbílis's nóg, ${ }_{3}$ ' Gospód'-bòg ná nebe skonchálsä, 4' I v áde sataná iz $\underline{\text { dókh. }}$

The monosyllable no[x] ('legs') ${ }^{29}$ in the clausula of line TT-2' reflects the monosyllable No[t] ('a mishap'), which forms the clausula of line ST-2, whereas the semantics of the rhyming word is preserved in the translation: izdókh ('died') in line 4' corresonds to todt ('dead') in line 4.

Tiutchev's imitation of the fisher-boy's song from Schiller's drama Wilhelm Tell (1804) has the incipit "S ozera veet prokhlada i nega...", the epigraph "Es lächelt der See..., and the title "Iz Shillera" ("From Schiller", 1851). The Russian text begins with a phonetic quotation from the original: Es lä́chelt

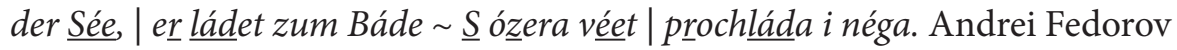
observed:

In this translation, besides a reproduction, probably accidental, of the individual sounds of the original (der See - S ozera, where the consonants coincide; der See - veet, where the vowels coincide: [namely], the slender $e$ ), we find a coincidence with the original in the group 'prokhlada' - 'er ladet'. [The Russian and the German segments are similar] in terms of the composition of sounds, their arrangement and their metrical position. (Fedorov 1928: 61) ${ }^{30}$

In each of the two strophes of Schiller's original, six lines are linked by two rhymes and one consonance. Each consonance is supported by the coincidence of post-tonic vowels ("Klíngen : Éngel" in the first strophe; Tíefen : Schläferer in the first strophe). In the first strophe of the TT a consonance, " $z v u \underline{\underline{k i}}$ : li $\underline{\underline{k i}}$ " (with coincident [i]-sounds in the post-tonic syllables), appears in the same metrical/strophic position as in the ST:

\footnotetext{
29 Part of the idiom, sbit'sia s nog ('be off one's legs').

30 Compare also the initial consonants of each hemistich: Es (lä́chelt) $\underline{S} o ́(z e r a) ;$ er ládet $\sim$ prochláda.
} 
${ }_{1}$ Es lächelt der Sée, | er ladet zum Báde

1, S ozera véet | prochlada i néga

${ }_{2}$ Der Knabe schlief ein am grünen Gestáde,

${ }_{3}$ Da hört er ein Klíngen,

${ }_{4}$ Wie Flöten so súuß

${ }_{5}$ Wie Stimmen der Éngel

${ }_{6}$ Im Paradíes.

${ }_{2}$ Otrok zasnul, ubajukan u bréga.

3' Blazhennye zvúk $\underline{\text { i }}$

4'On slyshit vo sné

5' To angelov líki

${ }_{6}$ 'Pojut v vyshiné.

Among other things, the vowel hiatus, which is copied in the TT (graphically and, to a certain extent, phonetically: See ['ze:] veet ['vjeet] or ['v'eIt]), finds a telling parallel in the grapho-phonetical structure of one of the clausulae in Tiutchev's translation (1826) of Heine's most celebrated poem, "Ein Fichtenbaum steht einsam..." (“A spruce-tree stands all alone..., 1823): “... Umhüllen ihn Eis und Schnee " “..I son ego burä leléet”. Another dazzling hiatus that may be recalled here is an allusion to Goethe's "Willkommen und Abschied" ("Welcome and farewell", 1775) in Tiutchev's original poem, "Pesok sypuchij po koleni..." (“The crumbling sand is knee-high..., 1830):

Nóch’ khmúraja, | kàk zvér’ stoókij, [...] Wò Fínsternìß | aus dem Gestrắuche

Glädít iz kázhdogo kustá!! Mit húndert schwárzen ̂ugen sáh.

Not only the image of "darkness (Finsterniß) / night (noch')" as a creature "with a hundred eyes" (mit hundert Augen $=$ stookij) $)^{31}$ (see Briusov 1900: 410), but the metre, syntax and the acoustic structure of the clausulae coincide in both poems. Judging by this context, the correspondence between the hiatus in stookij and the diphthongs in the German text does not appear incidental.

Fedorov (1928: 62) found an example of a precise imitation of sounds in the clausula in Tiutchev's translation of the harp-player's second song from Goethe's Wilhelm Meisters Lehrjahre ("Wer sich der Einsamkeit ergibt..."): Mich Éinsamen die Quál [...] Krugòm menä pechál’!.. (the Russian text is dated 1827-1830 and begins "Kto khochet miru chuzhdym byt'..."). This example is even more interesting as the structure of the rhymes in both ST and TT is not identical. A reproduction of the [-ax] rhyme from Mignon's song, in both Zhukovsky's and Tiutchev's translations (also noticed by Fedorov), was already discussed above.

Similar phenomena occur (albeit less frequently) in the translations from German made by Tiutchev's younger contemporaries, such as Mikhail L. Mikhailov (1829-1865) and Afansy Fet (1820-1892).

31 Presumably, Argos Panoptes in Goethe's poem. In Tiutchev, it is called 'a beast' (zver'). 
Thus, Yuri D. Levin noticed that the concluding line of the penultimate stanza from Heine's "Die Grenadiere" ("The Two Grenadiers", 1822) in the definitive redaction of Mikhailov's translation $\left(1846^{1}, 1858^{2}\right)$, which reads “...Und wiehernder Rosse Getrabe”, is rendered “in a clattering line: 'I pushechnyj grom i trubu'. (It is illustrative that Mikhailov introduced 'the trumpet' [truba], which is absent in the original, in order to reproduce the acoustic ending of the stanza, Getrabe ['the hoofbeat'], as close as possible)" (Levin 1985: 210, cf. 208-209). It should be added that Getrabe rhymes with "im Grabe" ('in the grave'), which is conveyed in the TT both phonetically and semantically as " $v$ grobu" ('in the grave'):

So will ich liegen und horchen still,

${ }_{2}$ Wie eine Schildwach, im Grábe,

${ }_{3}$ Bis einst ich höre Kanonengebrüll

${ }_{4}$ Und wiehernder Rosse Getrábe. ${ }^{32}$
${ }_{1}^{\prime}$ I smirno i chutko ja budu

2' Lezhat', kak na strazhe, v grobú.

3'Zaslyshu ja konskoe rzhan'je

${ }_{4}^{\prime}$ I pushechnyj grom, i trubú. ${ }^{33}$

Fedorov discovered "abundant examples of acoustic coincidences determined by the phonetics of proper names" in the translations from German made by the late romantic poet Afanasy Fet (Fedorov 1928: 63). Just like Zhukovsky and Tiutchev, Fet liked to preserve proper names in the clausula. Such is, for instance, the rhyme "Admét : Filoktét" ('Admetus : Philoctetes') ${ }^{34}$ in his version (1878) of Schiller's “Götter Griechenlandes" (“The Gods of Greece”, 1788', $1800^{2}$ ). In this translation, which Fet himself characterized as "made in the metre of the original and almost literal” (Fet 1971: 686), the phonetic structure of the rhyme is also preserved when only one of the rhyming words is a proper name, such as "Mänáden : <ein>láden" (ST) - it is copied as "Menády : vzglä́dy" (TT). ${ }^{35}$ Finally, the rhyme "<Demeters $>[\widetilde{\mathrm{ts}}] \ddot{a}[\mathrm{~s}] e:[\widetilde{\mathrm{ts}}] y[\mathrm{t}] e ́[\mathrm{~s}] e^{\text {” is }}$ copied as "[ $\mathrm{ts}]$ eré $[\mathrm{r}] a$ : [ [s] $] i[\mathrm{t}] e ́[\mathrm{r}] a$ " (ST): ${ }^{36}$

\footnotetext{
32 'So shall I lie and listen silently / like a sentry in my grave, / till one day I hear the cannon's roar / and the hoofbeat of neighing horses'.

33 'And I shall quietly and keenly / lie like a sentry in my grave. / I shall hear the neigh of horses / and cannon's roar, and the trumpet'.

34 Resp. "Admét : Philoktét" in the ST.

35 'Menades : invite' (ST); 'Menades : <his > looks' (TT).

36 '<Demeter's $>$ tear : Cythera' (ST); 'Ceres : Cythera' (TT).
} 


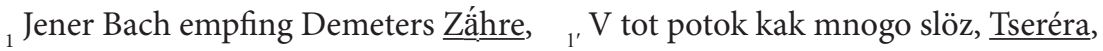

${ }_{2}$ Die sie um Perséphone geweint, $\quad{ }_{2}^{\prime}$ Ty o Persefóne prolila,

${ }_{3}$ Und von diesem Hügel rief Cythére, $\quad{ }_{3}^{\prime}$ A s togo kholma votshche Tsitéra

${ }_{4}$ Ach, umsonst! dem schönen Freund. $\quad{ }_{4}^{\prime}$ Druga nezhnogo zvala.

The correspondence is both phonetic and semantic because, as Fedorov put it, "Tserera ['Ceres'] translates the word Demeter, its equivalent. ${ }^{37}$ This is especially interesting in view of the proximity of its sounds to the word Zähre" (Fedorov 1928: 64).

\section{Mandelshtam's translation techniques}

A successor of the poetics of Zhukovsky and Tiutchev was Osip Mandelshtam, who is sometimes credited with being the best Russian-language poet of the twentieth century. His words about verses living through the "ringing mold of form that anticipates the written poem" were quoted above. Such an attitude manifests itself in his translations as well as original poetry.

In the winter of 1933-1934 Mandelshtam translated four sonnets from Petrarch's Canzoniere. In these translations he attempted to re-create not only the rhythmic structure of the original, ${ }^{38}$ but also its acoustic instrumentation. In many examples the translator's rejection of lexical and phraseological faithfulness is compensated by a close imitation of the phonetic structure of the ST, first and foremost in the rhymes (see Semenko 1970: 169; Mureddu 1980: 66, 73-74, 77; Pilshchikov 2010: 112-113).

Irina Semenko (1970: 169) compared the concatenation of rhymes in Petrarch's sonnet CCCI with that in Mandelshtam's translation (Mandelshtam 1990: 204):

37 The Roman goddess Ceres was seen as the counterpart of the Greek goddess Demeter.

38 For the discussion see Semenko 1970: 168-169; Iliushin 1990: 374-376; 2004: 216-217; Venclova 1991: 197; Pilshchikov 2010: 109-110. 


\begin{tabular}{|c|c|}
\hline piéña & solönykh \\
\hline crésci & moglí by \\
\hline pésci & rýby \\
\hline affréna & zelö́nykh \\
\hline seréña & kalönnkh \\
\hline riésci & izgíby \\
\hline rincrésci & glíby \\
\hline ména & sklónakh \\
\hline fórme & méste \\
\hline víta & graníta \\
\hline dóglia & vesélij \\
\hline órme & chésti \\
\hline gíta & mýta \\
\hline spóglia & postéli \\
\hline
\end{tabular}

One rhyme is precisely reproduced in terms of its phonetic structure (" $\underline{\text { ita }}$ : gíta" "granita: mýta"), in two other rhymes the onset consonant of the post-tonic syllable of the clausula in the TT and ST are similar $([\mathrm{li}] \sim[K])$ or coincide $([\mathrm{n}] \sim[\mathrm{n}])$.

In his translation of sonnet CCCXI, Mandelshtam (1990: 205) preserves the sonorant trill $[\mathrm{r}]$ in the clausulae of the tercets:

s’assecúra : oscúra : ventúra : dúra; chiári : impári

strákha : prákha : prắkha : vzmákha; efíra : míra

Tomas Venclova (1991: 197) also noticed that the Italian rhymes ending in -ári (chiári : impári) find a "palindromic" correspondence in the Russian rhymes ending in -íra (efíra : míra). In the beginning of the fifth line of this sonnet, Semenko (1970: 169) discovered an example of lexical and semantic accuracy reinforced by phonetic precision: "Et tútta nótte..." "I vs $\underline{u}$ - to nóch'..." (both the Italian and the Russian phrase mean 'and all night long').

Mandelshtam's version of sonnet CLXIV (Mandelshtam 1990: 205) also features a striking interlinguistic facsimile: the Russian poet copied Petrarch's rhyme "víva : a ríva" as "raznorech $\underline{i v a}:$ na dívo

39 Due to vowel reduction in Russian, the unstressed /a/ and /o/ merge in [ə] in the post-tonic syllables. This sound is perceived as an allophone of /a/ (so-called ákanye). 
strikingly, "Petrarch's táce, giáce, sfáce, páce ${ }^{40}$ are rendered with phonetically

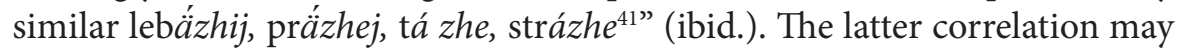
of course be incidental, but all verses in Mandelshtam's text, and not only its rhymes, are permeated with hushing sibilants [J], [t] ] and [z] (Mureddu 1980: 77-78). It seems most likely that Mandelshtam emphasized the presence of similar sounds in the Italian original because the abundance of sibilants and affricates formed part of his own acoustic image of the Italian language, which opposed the established romantic concept of the extraordinary "melodiousness" of Italian (see Venclova 1991: 197-198; Pilshchikov 2012; 2015: 141-149, 155-156).

Another example of phonetic facsimile in the clausulae is found in Mandelshtam's translation of sonnet CCCXIX (Mandelshtam 1990: 206), where he reproduced one of the rhymes in the quatrains (Semenko 1970: 169):

béne : seréne : spéne: téne

olénej : naslazhdénii : obol'shchénij : spleténiij ${ }^{42}$

The second redaction of the translation has "olénej: $v$ péne $:$ koléni : razvetvlénij"; the third redaction - "olénej: v péne : javlénij : v tléne" (Mandelshtam 1990: 403-405). The rhyming words change, but the rhyme remains the same (see Gasparov 2002: 325-329 for the discussion).

The rhymes in the tercets of the same sonnet contain a sequence of onset sonorant consonants in the post-tonic syllables, "[r]-[1]-[r] [l]-[r]-[1]", which is mirrored as the inverted sequence " $[1]-[\mathrm{r}]-[\mathrm{l}][\mathrm{r}]-[\mathrm{l}]-[\mathrm{r}]$ " in the translation:

$\begin{array}{ll}\begin{array}{l}\text { anchóra } \\ \text { ciélo } \\ \text { m’innamóra }\end{array} & \begin{array}{l}\text { sushchestvoválo } \\ \text { lazúríi } \\ \text { byválo }\end{array} \\ \text { pélo } & \text { khmúrää } \\ \text { dimóra } & \text { pristála } \\ \text { vélo } & \text { búräa }\end{array}$

40 All rhyming in [-'atfe].

41 All rhyming in [-'azi $]$.

42 Unstressed /e/ and /i/ merge in the post-tonic syllables. 
The Italian text of sonnet CCCXIX begins: "I dì miei più leggier, che nessun cervo, / Fuggir com' ombra e non vider più bene..." ("My days, more swiftly than any deer, / Have fled like a shadow and have seen lesser good..."). Mandelshtam's translation begins: "Promchalis' dni moi - kak by olenej..." ("My days have swiftly passed, as if of the deer.. "). Gasparov, who analyzed the relationship between these texts, noticed that 'the word cervo ['a deer'] is placed at the end of the [first] line, the word olenej ['of the deer', plural] is also placed at the end of the first line, whereas the sound of olenej repeats the rhyme of the second Italian line, "più bene"' (Gasparov 2002: 331). This example of double correlation is of the same nature as the analogous examples from Zhukovsky and Tiutchev discussed in some detail above. One word in the TT refers to two different words in the ST; one of these references is based on lexical semantics, the other on phonetics.

Viacheslav Ivanov, Mandelshtam's mentor in poetry and himself a prominent translator of Petrarch, proclaimed his adherence to Zhukovsky's principles of translation. For Ivanov, "the supreme goal" of translation was "to create the musical equivalent of the original". He was confident that "the letter [i. e. literal translation] kills" and proposed to "sacrifice the literal proximity of lineby-line transposition" in the name of "a faithful interpretation" of the poetic original (quoted in Venclova 1991: 193-194). Unlike Ivanov, Mandelshtam took up the Zhukovskian tradition not only in theory, but also in practice, and prioritized the acoustic aspect of translation over the strict reproduction of the literal meaning. It is no surprise then that in terms of versification, Mandelshtam's free improvisations on Petrarchan sonnets are closer to the prosody of the Canzoniere than all earlier translations into Russian except those of Mikhail Kuzmin, another acmeist poet (see Pilshchikov 2015: 152154). ${ }^{43}$ Mandelshtam, who was irritated by the Russian tradition of translating Petrarch "in boring iambic pentameters or theatrical alexandrines", ${ }^{44}$ broke with this tradition and undermined the syllabic-accentual iambic inertia. The prosody of his imitations of Petrarch, with their continuous feminine rhymes (unusual for Russian classical catalexis) and numerous instances of trochaic

43 Kuzmin's translations from Petrarch, made in 1928, remained unpublished until recently (see Dmitriev 1996).

44 Reported in the memoirs of the poet Semen Lipkin (1991: 21) quoted by Venclova (1991: 196). 
"trans-accentuation" (which imitate the cadence of syllabic verse) ${ }^{45}$ becomes a signifier of the Italian poetic tradition. ${ }^{46}$

\section{Sound, rhythm, and syntax}

Many phonetically translated fragments can be described as the result of a multi-layered reinterpretation of the ST intonation, the ST system of word boundaries, and the metrical-rhythmical structure of ST words in the TT. In this context, 'intonation' is understood as the relationship between the metrical and rhythmical organization of the poetic text, on the one hand, and its syntactic structure, on the other. In his innovative study of the relationship between rhythm and syntax, The Melodics of Russian Lyric Verse (1922), Boris Eikhenbaum wrote:

Poetic syntax is constructed in close connection with rhythm - with verse and strophe. It is a conventional, deformed syntax. It changes from a simple grammatical form into a formant. The poetic phrase is not a general syntactic phenomenon, but a rhythmic-syntactic phenomenon. Moreover, poetic syntax is not only a phenomenon of phraseology, but also a phonetic phenomenon: the intonation actualized in syntax plays no less important a role in the verse line than rhythm and instrumentation and sometimes plays an even more important role. In a verse line, the syntax, which actualizes intonation, is not articulated in semantic segments, but in rhythmic segments: sometimes it coincides with a rhythmic segment (a line $=$ a phrase), and sometimes it surmounts it (enjambment). Thus, it is in syntax regarded as a construction of phrasal intonation that we observe the factor which connects language with rhythm. (Eikhenbaum 1922: 5-6; cf. 1924 [1921]: 211-214)

45 For the discussion and varying views see Iliushin 1990: 374-376; 2004: 216-217; Plungian 2013; Pilshchikov 2010: 109-110; 2015: 143-145, 153-154.

46 It is known that Mandelshtam did not like the style of Mikhail Lozinsky's translation of The Divine Comedy, of which Mandelshtam knew only the first fragments and which was to become the standard translation of Dante for many generations of Russian readers (see Mandelshtam 1997: 183). Incidentally, in this translation "Lozinsky, with great skill and often very successfully, repeats the dominant sounds of the Italian original, sometimes at the expense of a partial loss of the semantic content of a particular word" (Bazzarelli 1976: 321). Similar features have been found in Lozinsky's translation of Shakespeare's Hamlet (Semenenko 2007: 92). 
Eikhenbaum primarily discussed interlinear syntax, but his theory can also be applied to intralinear syntax, which has an impact on the distribution of word boundaries in the verse line. The analysis of the system of word boundaries is important for a comparison of the versification parameters of the ST and TT because the rhythm of a verse line is determined not only by the distribution of accents in the line, but also by the "metrical structure of the words in it" (Kiparsky 1977: 224), that is, by the "distribution of word boundaries in verse and its interrelation with the network of accentual oppositions" (Jakobson 1979: 586). ${ }^{47}$

Without a syntactic and intonational similarity between the ST and TT, their phonetic resemblance may be insufficient to produce a similar acoustic impression. We have already discussed the fact that the Russian symbolist poet Valery Briusov was sensitive to "verbal music" and became one of the first theorists of "acoustic instrumentation" in Russian poetry. However, Briusov's attempt at phonetic translation was once criticized precisely because of its infidelity to the syntactic and intonational peculiarity of the original. Andrei Fedorov (1928: 62) analyzed the first quatrain from Briusov's translation (1909) of Théophile Gautier's "Carmen" (1852) as an example of what I referred to as an interlinguistic/intertextual rhyme (" $2: 4=2^{\prime}: 4^{\prime \prime \prime}$ ):

${ }_{1}$ Carmen est maigre - un trait de bistre

${ }_{2}$ Cerne son œil de gitana.

${ }_{3}$ Ses cheveux sont d'un noir sinistre;

${ }_{4}$ Sa peau, le diable la tanna. ${ }^{48}$
1'Onà khudá. Glazá kak slívy;

${ }_{2}$, V nìkh úgol' sprắtala onà; ${ }^{49}$

3' Zlovéshchi kós ejồ otlívy;

4' Dubíl ej kózhu sataná. ${ }^{50}$

The verse theorist Leonid Timofeev objected to this:

\footnotetext{
47 Metre is realized in the poetic line both as an individual rhythmic variation and as a wordboundary variation (to use the terminology established in Gasparov 1974: 14-15). Georgy Shengeli, who called the rhythmical variation of a metre the rhythmic "form" of a metre, invented a special term to denote a word-boundary variation: a "modulation" (Shengeli 1923: 38, 57 et passim, 138 et passim). "Word boundary" is Jakobson's translation of Osip Brik's term slovorazdel.

48 'Carmen is lean - a trait of bistre / Circles her gipsy eyes. / Her hair is a sinister black; / her skin - it is tanned by the devil'.

49 Pronounced as [e'na].

50 'She is lean. Her eyes are like plums; / She hid coal in them. / The tints of her plait is sinister; / the satan tanned her skin'.
} 
The common opinion that a translation is accurate if it preserves the rhythm and rhymes of the original leads to a situation where the translator forgets about the intonational and syntactic organization of the verse, which is key to its expressiveness. The following line from V. Briusov's translation of T. Gautier's "Carmen” may seem a model of the high accuracy of the translation, which preserved even the acoustic colouration of the original: "Sa peau, le diable la tanna" is translated as "Dubil ej kozhu satana". "Sataná" and "tanná" are very close indeed, but the peculiarity of this line consists in something very different: it consists in a bipartite intonational structure, an exclamation in the middle of the line and a sui generis answer to this exclamation in the second part of this line. Briusov's translation completely eliminates this individual intonational peculiarity of the line under consideration, and thus ignores its inner content. (Timofeev 1958: 129-130)

As if answering to Timofeev's criticism, Ariadna Efron, daughter of the outstanding poet Marina Tsvetaeva and a poet herself, attempted to reproduce Gautier's syntax in her translation (1971) and even emphasized the syntactic pauses by dashes, using her mother's favourite poetic device:

Ejö kosa - chernej mogily,

Ej kozhu - satana dubil. ${ }^{51}$

A description of the system of word boundaries would be incomplete if it did not take into account the fact that different word boundaries have different depths (this was demonstrated by Lucien Tesnière in his Elements of Structural Syntax): the hierarchy of the breaks between the words "corresponds to the hierarchy of syntactic relations" (Tesnière 1965: 26-27). Tesnière demonstrated that the depth of the breaks can be determined only relatively, that is in relation to other breaks in the same phrase (ibid.: 27). ${ }^{52}$ However, a fixation of such relative depths is sufficient for our analysis. The weaker the syntactic relation between the words, the weaker the phonetic fluency and, therefore, the deeper the word boundaries. ${ }^{53}$

51 'Her plait - is darker than the grave; / her skin - the devil tanned it'.

52 To describe what is referred to here as word boundaries or breaks, Tesnière uses the term coupures: “[...] les coupures nont pas de valeur absolue, mais seulement une valeur relative, c'est-à-dire que l'on ne saurait mesurer la profondeur d'une coupure en soi, mais seulement par rapport à d'autres coupures" (Tesnière 1965: 26).

53 For a discussion of the correlation between syntactic coherence and phonetic fluency see Testelets 2001: 77-79. 
In many of the following examples, the metric structure of words and the distribution of word boundaries in the TT and ST coincide despite the fact that the linear realizations of syntactic structures differ in terms of surface syntax due to the differences between the sets of the syntactic links in the ST and TT. Nevertheless, these links create similar configurations, whose resemblance determines a similar intonation of word boundaries, that is, the commensurability of their "depth" in the original line and the translated line. A characteristic detail here is the phonetic parallelism between words that have the same metrical position in the ST and TT. Thus, in the example from Zhukovsky's "Lenora" that was already discussed above:

$$
\begin{aligned}
& \text { Was | hálf || was | hálf || mèin | Béten } \\
& \text { Pred | ním || mòj | krík || bỳl | tshchéten - }
\end{aligned}
$$

the syntactic link between the first and the second word in the line is stronger than the link between the second and the third word; the link between the third and the fourth word is stronger than the link between the fourth and the fifth word; the link between the fifth and the sixth word is stronger than the link between the fifth and the fourth word. ${ }^{54}$ The same type of correlation between sound and syntax is found in other examples from Zhukovsky's translations discussed above:

$$
\begin{aligned}
& \text { Lúft und Wógen || álso | schwíeg } \\
& \text { Móre || vózduch || béreg | dík } \\
& \text { Sélig | préis'ich || Polyxénen } \\
& \text { Sládkij | zhrébij || } \underline{\text { Poliksény! }} \\
& \text { Dénn || den bésten | der Hellénen } \\
& \text { Vzór || lübóv'ju | raspalénnyj }
\end{aligned}
$$

Evidently, the strength of the syntactic links can be better described not in terms of dependency syntax, the forerunner of which was Tesnière's "structural syntax", but in terms of constituency syntax (or phrase structure grammar) (cf.

\footnotetext{
54 Compare Shengeli's insightful observation that the difference between various spondaic "modulations" in iambic and trochaic lines depends on the presence or absence of "a pause between the phrases" (Shengeli 1923: 35).
} 
Testelets 2001: 113 et passim). ${ }^{55}$ The closer two adjacent words in a verse line are on a constituency tree, the stronger the link between them. The measure of this proximity is the length of the path (i. e. distance) between two words along the branches of a constituency tree. In the linear representation of a constituency structure, the depth of the breaks between two words will be measured by the number of brackets which denote the boundaries of phrase groups:

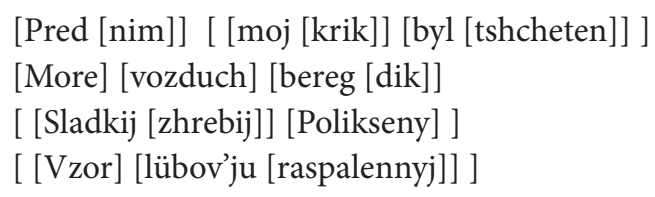

A fascinating example is the opening stanza of "Lenora":

1, Lenóre fúhr ums Mórgenròt

${ }_{2}$ Empór aus schwéren Trấumen:

3 "Bìst úntreu, Wílhelm, òder tót?

${ }_{4}$ Wie lánge willst du sắumen?
${ }_{1}$ Lenóre snílsja stráshnyj són,

${ }_{2}^{\prime}$ Prosnúlasä v ispúge

3, "Gdè mílyj? Chtó s nim? Zhív li òn?

4'I véren li podrúge?"

In the initial line of the TT, the position of the first word of the ST and its phonetics (the name of the ballad's heroine) is preserved, ${ }^{56}$ as well as the tonic vowel of the rhyme:

Lenóre | fúhr || ums Mórgen i -rò̀t

Lenóre | sníl -sja || stráshnyj| són

However, in the third line of the translation the name of Lenore's beloved is missing. This fact gave Kaplinsky cause to argue that, in Zhukovsky's ballad, "proper nouns are regularly omitted" (Kaplinsky 1915: 18). Michael R. Katz analyzed the manuscript of Zhukovsky's translation and came to the conclusion that it "demonstrates how difficult it was for the poet to get any closer to the German original" (Katz 1976: 50). The scholar cited the heroine's apostrophe to his bridegroom, Wilhelm, as an example (ibid.). Indeed, the name of Wilhelm is absent from Zhukovsky's version, but it faithfully reproduces the

\footnotetext{
55 As Chomsky pointed out: "The phrase structure [of the sentence] [...] is closely related to its phonetic shape - specifically, it determines the intonation contour of the utterance represented" (Chomsky 2006: 26).

56 The Russian Dative form of this name (Nom. Lenóra; Dat. Lenóre) has the same ending as the German Nominative form (Nom. Lenóre).
} 
rhythm of the German text and the original structure of the word boundaries (including their relative depth):

Bìst | úntreu, || Wíl -helm, || òder | tót

Gdè | mílyj? || Chtó s nim? || Zhív li | $\underline{\text { òn}}$ ?

The ST monosyllable tot ('dead') has two correlates in the TT: one of them, the monosyllable zhiv ('alive'), is lexical and semantic; ${ }^{57}$ the other, the monosyllable on ('he'), is metrical and phonetic. Thus, the vocabulary and phraseology of the translation can be significantly different from those of the original. But then the translation can sound like the original.

A similar resemblance between the intonations in the original and translated text (with numerous instances of lexical and semantic divergence from the original) can also be found in passages whose length exceeds one line of verse. In other words, the same effect can be produced by means of interlinear syntax. For example, the first stanza of Zhukovsky's version of "Elysium" establishes equivalence with the ST at the level of a complex sentence. The syntactic and intonational segmentation, that is the distribution of the subordinate clauses in the metric schema, is almost identical in the ST and TT. ${ }^{58}$ The types of subordinate clauses in the ST and TT is different, but all of them are introduced by monosyllabic words, which occupy identical positions in the metric and stanzaic schema. Zhukovsky reproduces here what Tynianov, following Brik, referred to as "rhythmic-syntactic figures" (Tynianov 1977 [1922]: 394), and Eikhenbaum - as "melodic-syntactic figures" (Eikhenbaum 1922: 17). ${ }^{59}$ The boundaries of the subordinate clauses coincide with four masculine clausulae, and this intonational construction is cemented with a structure of masculine rhymes which resembles the original:

\footnotetext{
57 The questions, "Is he dead?" (ST) and "Is he alive?" (TT) may be considered semantically equal in this context.

58 Compare Semenko's observations concerning the role of intonation and syntax in Zhukovsky's poetics (Semenko 1975: 111-113).

59 Brik's unpublished paper "On Rhythmic-Syntactic Figures" was delivered to Opoyaz in 1920 (see Eikhenbaum 1927 [1925]: 135) and then cited in the first footnote to Eikhenbaum's The Melodics of Russian Lyric Verse (Eikhenbaum 1922: $5 \mathrm{ftn}$.). Brik's paper laid basis for his unfinished monograph Rhythm and Syntax, extracts from which were published in 1927 (see Brik 1927, 4: 28-29; 5: 33 et passim; cf. Erlich 1965: 89, 220-222; Jakobson 1979: 570, 584).
} 
Hein! der von der Götter Frieden,

Wie von Thau die Rose, träuft,

Wo die Frucht der Hesperiden

Zwischen Silberblüten reift;

Den ein rosenfarbner Aether

Ewig unbewölkt umfleußst,

Der den Klageton verschmähter

Zärtlichkeit verstummen heiß $3 t$ [...]

(Matthisson 1789: 106)
Roshcha, gde podatel' mira,

Dobryj genij smerti, $\underline{s}$ pit;

Gde rumänyj blesk efira

S ten'ju zybkikh senej s $\underline{\text { sit; }}$

Gde istochnika zhurchan'je

Kak dalekij otzyv li $r$;

Gde pechal', zabyv roptan'je,

Obretaet sladkij mir.

(Zhukovsky 1813: 201) $)^{60}$

All the words in the masculine clausulae (with the exception of umfleu $\beta t$ ) are monosyllabic. All the rhymes are closed syllables. In both German rhymes the nucleus vowel is a diphthong, and in both Russian rhymes the nucleus vowel is [i]. Therefore, the concatenated vowels of the rhyme bind the entire stanza into a whole. The first rhyme in the ST and TT is formed by a monosyllabic verb ending in [-t] (3rd person singular). The rhymes are rich: the same onset consonant $[\mathrm{b}]$ is found in both German words, and the same initial consonant of the onset cluster [s] is found in both Russian verbs. ${ }^{61}$ It is an eloquent fact that, when in September 1827 in Stuttgart Aleksandr Turgenev recited Zhukovsky's version in the presence of Matthisson, the German poet, who did not know Russian, recognized his own poem in translation and "admired the harmony of its language" (Turgenev 1872: 146-147; Gugnin 1985: 590; Vatsuro 1994: 130).

Much like Zhukovsky, Tiutchev paid close attention to both the phonetics of verse as well as poetic syntax. Tynianov found in the latter's translations from Heine "Tiutchev's usual concern for acoustic instrumentation and the syntactic construction of verse" (Tynianov 1977 [1922]: 393). "Thus, in his translations, Tiutchev is mindful, first, of instrumentation, second, of syntax, and third, of the vocabulary of Heine's poems, creating their rhythmical analogue" (ibid.: 387). In the same study Tynianov makes a more general statement based on his observations of Tiutchev's translation techniques and his analysis of Heine's influence on Tiutchev:

60 Tellingly enough, the punctuation in the first print of Zhukovsky's translation is closer to the German original than in later republications (esp. line 2; cf. Zhukovsky 1815: 236; and later editions).

${ }^{61}$ In the system of rhyming established in Russian classical verse, the coincidence of the onset consonants in closed rhymes is not obligatory. 
Both influence and borrowing can be manifested in poetry 1 ) in the field of rhythm and syntax, 2) in the field of instrumentation, 3) in the field of themes and images; and they can be carried out in all of these three fields [at the same time]. (ibid.: 388)

Mandelshtam's poetic syntax deserves special study, but, on the whole, he conveys Petrarch's syntax with more precision than, for example, Viacheslav Ivanov (see Venclova 1991: 195, 197; cf. Nelson 1986: 172-180; Gasparov 2001: 657). In particular, in Mandelshtam's translations we do not find excessive enjambments and numerous syntactic pauses within the verse, which are formed by short simple sentences. Such obvious elements of "modernist" syntax, typical of Ivanov's translations from Petrarch, strike the eye (and the ear) and did not escape the notice of critical contemporaries (see Fisher 1915: 274). ${ }^{62}$

It may be thus concluded that phonetic translation usually goes hand in hand with the re-creation of the intonational structure of the ST, which is formed not only by the rhythm of verbal accents, but also by the interrelationship of syntactic constructions with verse lines and stanzaic structures.

\section{Phonetic translation from the standpoints of poetics, semiotics, and psycholinguistics}

Language contact in the act of translation leads to language interference. Interference occurs at different levels but primarily affects syntax and phonetics, i. e. linguistic levels, which are, apparently, least of all susceptible to self-reflection and self-censorship (cf. Vekshin 2006: 20-21). On the other hand, the accurate transposition of sound, intonation and verse form at the expense and even to the detriment of imagery and ideas is a clear manifestation of the "law of compensation" in the poetics of literary translation (cf. Harvey 1998).

The problem of phonetic translation is related to some psycholinguistic issues. Experiments on the associations between acoustic sequences and named objects, which were performed by the Georgian psychologists of the Uznadze school in the 1960s and 1970s, revealed that the examinees "are not indifferent to which acoustic complex is used as the name of a certain content". During these experiments, "an acoustic complex was experienced as having

62 For the contrary view, see: Mureddu 1980: 66, 73-75; Balašov 1988: 31-36; Gasparov 2002: 335. 
a differentiated structure in which certain sounds are centered, while other sounds form a background" (Baindurashvili 1978: 189; cf. 1968) ${ }^{63}$ Each of these complexes is a quasi-syllabic "rhythmic and consonant-vocalic unity", or a "phonosyllabeme" (Vekshin 2006: 118 et passim). When we speak of alliteration, such quasi-syllables and their elements are singled out on the basis of what Brik (1917) termed "sound repetitions", i. e. reiterations of certain sounds and groups of sounds within a poetic text. Characteristically, sound repetitions are often associated with particular metrical positions and/or rhythmic groups (Brik 1917: 44). When we speak of "borrowings and influences", their elements are singled out on the basis of the repetition of certain phonetic and rhythmic groups of one text in another text (Bobrov 1922; Ronen 1997). The difference between these two types of repetition is the difference between intratextual and intertextual parallelism. When we speak of phonetic translation, the rhythmic and phonetic repetitions are not only intertextual, but also interlinguistic.

In his aforementioned article, "On the Sounds of Poetic Language", Yakubinsky argued:

In poetic linguistic thinking the sounds emerge into the bright field of consciousness. In connection to this, an emotional attitude toward [these sounds] arises, which in turn brings about the establishment of a certain relationship between the "content" of a poem and its sounds. The latter is reinforced also by means of the expressive movements of the speech organs. (Yakubinsky 1916: 30, emphasis in the original $)^{64}$

In the case of phonetic translation the acoustic and articulatory complexes of the ST are transposed into the TT. The translator apparently associates them with the "content" of the ST, and these associations may prove more durable than the intertextual relations generated by lexical substitution (when each particular word or phrase of the TT is substituted for a particular word or phrase in the ST). If a text or its fragment is translated phonetically, the correlation between sound and meaning is transferred from one language to the other. ${ }^{65}$ Typically, the original phonosyllabic complex is not reproduced in its entirety, but substituted with a few support components. These components may be described as "consonant-vocalic configurations" (Vekshin 2006: 112):

${ }^{63}$ Similarly, pets identify their name or a command on the basis of a few central sounds.

64 The translation is taken from Pomorska (1968: 30) and slightly modified.

${ }^{65}$ A similar, but in many respects different phenomenon is the translation of anagrammatic texts (see Baevsky 1976; cf. Taranovsky 1966). 
they consist of several "central" sounds which normally occupy a metrically and/or rhythmically marked segment (for example: the clausula; the clausula and the caesura; the clausula and the second foot of the trochaic or iambic tetrameter; and so on). The rhythmical basis of acoustic instrumentation was emphasized in the works of the Russian formalist Osip Brik (1917: 44) and, later, the Czech structuralist Jan Mukařovský, who confirmed that "euphony usually requires additional support in the rhythmic, syntactic, or semantic articulation of the context" (Mukařovský 1976 [1940]: 27). Here, perhaps, a broader regularity manifests itself, which was described by the renowned Russian linguist Lev Shcherba:

It seems to me $[. .$.$] that a poet's acoustic image should be extremely heterogene-$ ous in terms of its brightness: some elements appear before him with great force [...], others are in the shadows, and some are almost inaudible [...] Such a concept would correspond to what we generally observe in language, where we can always distinguish between the important, the essential, [on the one hand], and, so to say, "packaging material" [on the other]. (Shcherba 1923: $28 \mathrm{ftn}$.)

Another fundamentally important question is this: what kind of semiotic mechanisms come into play when the phonetic aspects of a translation are brought to the foreground? Georgy Levinton considered the phenomena under discussion as phenomena on the border between translation proper and citation - as phonetic (but also rhythmical etc.) allusions to the original, or rather "quotations from the original" (Levinton 1986: 17). Language interference activates the workings of citation, in which the reference to extralinguistic reality is complemented with an intertextual (linguistic) reference (the reference from one signifier to another). According to Jakobson, "split reference" is characteristic of any poetic text: "The supremacy of the poetic function over the referential function does not obliterate the reference but makes it ambiguous" (Jakobson 1960: 371). Psycholinguists agree: "When we deliberately attend to specific words, for example in the subtle matter of reading poetry", we pay special attention to sounds, which "do not so much contribute to a literal interpretation as establish a different - a complimentary or alternative - kind of mood or meaning" (Smith 1978: 162). Phonetic translations attempt to convey this "complimentary or alternative" meaning.

Mihhail Lotman compared the semiotic "split" or "shift" in phonetic translation with the concept of text as a "palimpsest" in the writings of Jacques Derrida and his followers (Lotman 2009). As an alternative to the concepts of "palimpsest" and "intertext", the concept of "subtext" can be used to describe 
phonetic translation. It was introduced by Kiril Taranovsky and his school, who focused on the role of allusion and quotation in the poetics of Mandelshtam, and, independently, by the Soviet linguist Tamara Silman. The latter defined "subtext" as "nothing else but a dispersed and distanced repetition" (Silman 1969: 85). Omry Ronen, a student of Taranovsky who contributed greatly to the theory and practice of subtextual analysis, agreed with this definition, but with one qualification: "[...] we call a subtext not the repetition itself, but what serves as an object of repetition or a source of the reiterated element" (Ronen 1973: 376 ftn.; cf. Tammi 1991: 316-327; Ronen 2012).

Not only a foreign text, but a foreign language can serve "as a subtext" (Levinton 1979). From this point of view, it would be interesting to compare a "split" of intertextual/interlinguistic reference that manifests itself in phonetic translation with bilingual puns, such as Mandelshtam's "Feta zhirnyj karandash" ('Fet's fat pencil', cf. German Fett 'fat'). In this kind of interlinguistic game, which Mandelshtam seems to have enjoyed, "one word, which substitutes for a foreign word, is its paronym, and another is its synonym (or, rather, heteronym)" (Levinton 1979: 32-33). Similarly, phonetic translation can equally be called paronymic, homophonic or homonymic translation. Its genesis is common with the genesis of poetry itself. When Viacheslav Ivanov described it as an "immediate mutual attraction of homonyms" (1930: 96), he was, in fact, quoting Shklovsky who claimed that:

in poetry, words are selected as follows: a homonym substitutes for a homonym to express the inner, earlier given sound-speech [zvukorech'], and not a synonym for a synonym to express the nuances of a concept. (Shklovsky 1916: 10)

Viktor Grigor'ev, a scholar of Russian futurism, called this phenomenon "paronymic attraction" (Grigor'ev 1979: 251 et passim). This term was proposed by the French linguist Albert Dauzat who, however, described another linguistic mechanism: popular, or folk etymology (Volksetymologie). Dauzat initially called it "homonymic attraction" (Dauzat 1922: 72 et passim), but later put forward another term, "paronymic attraction" (Dauzat 1927: 109). In this process, the word of a foreign language is reanalyzed and replaced by its paronym, which, in fact, has a different inner form (such as sparrow-grass for asparagus) ${ }^{66} \mathrm{~A}$ direct analogue of Volksetymologie in poetry is what Leonard Forster (1970: 92) called "surface translation". In this situation the translator

${ }^{66}$ On the relationship between phonetic translation and folk etymology see, in particular, Àlàbá (1981) and Toury (1990). 
deliberately changes the meaning of a well-known text while delicately preserving its sound (Forster 1970: 91-93). An often quoted example is Luis van Rooten's celebrated French version (1967) of "Humpty Dumpty":

Un petit d'un petit

S'etonne aux Halles

Un petit d'un petit

Ah! degrés te fallent, etc.

If spoken aloud, it sounds like the original English poem recited with a French accent: "Humpty Dumpty sat on a wall, / Humpty Dumpty had a great fall" etc. Gérard Genette, however, prefers to categorize such a transphonation as an "interlinguistic homophonic transformation": "The procedure generates utterances that are presumably devoid of meaning", he argues, and "the term 'translation' is therefore misused here” (Genette 1997 [1982]: 40-41). But do we always need "meaning" in translation (and in poetry)? "A poem should not mean / But be".

The "separability" of phonetics and graphics "for translation purposes" described by J. C. Catford is made possible thanks to the relative autonomy of instrumentation and prosody in a poetic text. Such autonomy is in turn conditioned by the efficacy of the poetic/aesthetic function - the orientation of enunciation "toward the message as such" (Jakobson 1960: 356). According to Červenka, who developed the ideas of Jakobson and Mukařovský, the poetic function "focuses attention on the message itself, foregrounding its acoustic level (which is independently active from the point of view of meaning)" (Červenka 1993: 118), so that

the acoustic elements, whose distribution in ordinary texts is determined only by the expression of a previously given content [...], create, in artistic texts, the autonomous formations, which emerge simultaneously with higher semantic units and interact with these units [...] as well as with each other [...], i. e. in the sphere of the artifact. (Červenka 1993: 129) ${ }^{67}$

The word in poetic speech "is located at the intersection of two series", a semantic series and a relatively autonomous (eu)phonic series. As a result, there emerges "a space, which enables the creation of configurations that are

\footnotetext{
67 In Mukařovskýs semiotics of art, an artistic text as a sign is composed of an artifact (or a "work-thing"), an "aesthetic object", and "a relation to the thing signified" (Mukařovský 1978 [1934]: 88).
} 
independent from the needs of reference" (Červenka 2002: 28-29). The existence of such a space is made possible by speech flexibility which is in turn secured by language redundancy (ibid.). In everyday speech, redundancy plays a subsidiary role: it increases the predictability of a text and thus suppresses information noise. In poetic speech, these linguistic tools are used to create an autonomous semiotic system.

In his paper delivered at the Jakobson Centennial Congress, the Moscow linguist and semiotician Aleksandr Barulin described the phonetic structure of one of Zhukovsky's poems. He argued that the instrumentation of a poetic text can acquire "symbolic, structural and semantic functions, and step forth in a poem [...] as an ad-hoc non-verbal semiotic system, i. e. a semiotic system, which is constructed for a specific purpose for a given portion of a text" (Barulin 1999: 697). According to Barulin's definition, "ad-hoc semiotic systems" are such semiotic systems (including onomatopoeic semiotic systems), which are "produced in the process of communication and usually disappear after they are no longer necessary" (Barulin 2007: 26, cf. 2007: 27, $34 ; 2002: 275-277)$. A new "ad-hoc system" is created with each new translation of a text. Juri Lotman once noticed that "each artistic text is created as a unique sign with a particular content, constructed ad hoc" (Lotman 1977: 22). However, cultural texts do not usually "disappear" after use, but continue to exist: the original continues to exist even after the appearance of its translation; the translation often continues to be enjoyed even after the emergence of a new translation of the same text. Moreover, the consumer of culture is able to perceive both the original and the translation; the translation against the background of the original; and new translations against the background of the older translations and the original. As a result, the "source text" (i. e. the original) starts to function as a "subtext", so that each translation - and phonetic translations in particular - can manifest a certain non-verbal content. ${ }^{68}$

\section{References}

Àlàbá, Olúgbóyèga 1981. Natural versus artificial translation: a case for folk etymology. In: Babel 27(1), 17-20.

Averintsev, Sergei Segeevich 1988. Razmyshlenija nad perevodami Zhukovskogo. In: Troitsky, Vsevolod Yurevich (ed.), Zhukovskij i literatura kontsa XVIII - nachala XIX v. Moskva: Nauka, 251-275.

68 I would like to express my gratitude to Michael Lavery who helped with editing this article. 
Baevsky, Vadim Solomonovich 1976. Fonika stikhotvornogo perevoda: Anagrammy. In: Nikol'skaya, Liudmila Il'inichna (ed.), Problemy stilistiki i perevoda. Smolensk: Smolenskij gosudarstvennyj pedagogicheskij institut imeni Karla Marksa, 41-50.

Baindurashvili, Akaky Georgievich 1968. Problema naimenovanija v eksperimental'noj psikhologii (Avtoreferat dissertatsii na soiskanie uchenoj stepeni doktora psikhologicheskikh nauk). Tbilisi: Izdatel'stvo Tbilisskogo universiteta.

Baindurashvili, Akaky Georgievich 1978. Nekotorye charakternye osobennosti rechevogo znaka $v$ aspekte problemy real'nosti bessoznatel'nogo psichicheskogo. In Prangishvili, Aleksandr Sever'ianovich; Sheroziya, Apollon Epifanovich; Bassin, Filipp Veniaminovich (eds.), Bessoznatel'noe: Priroda. Funktsii. Metody issledovanija. Tbilisi: Metsniereba, 187-198.

Balašov, Nikolaj Ivanovič 1988. La taxinomie des sonnets de Pétrarque et leur syntaxe dans les traductions de Vjačeslav Ivanov. In: Malcovati, Fausto (ed.), Cultura e memoria: Atti del terzo Simposio Internazionale dedicato a Vjačeslav Ivanov (Pubblicazioni della Facoltà di lettere e filosofia dell'Università di Pavia 45). I: Testi in italiano, francese, inglese. Firenze: La Nuova Italia, 21-36.

Barulin, Aleksandr Nikolaevich 1999. Funktsii alliteratsii v elegii V. A. Zhukovskogo "More". In: Baran, Henryk; Gindin, Sergei Iosifovich (eds.), Roman Jakobson: Teksty, dokumenty, issledovanija. Moskva: RGGU, 696-714.

Barulin, Aleksandr Nikolaevich 2002. Osnovanija semiotiki. Znaki, znakovye sistemy, kommunikatsija. T. 1: Bazovye ponjatija. Evoljutsionnaja teorija proiskhozhdenija jazyka. Moskva: "Sport i kul'tura-2000”.

Barulin, Aleksandr Nikolaevich 2007. K postroeniju teorii glottogeneza. In: Kochergina, Vera Aleksandrovna (eds.), Lingvisticheskaja komparativistika $v$ kul'turnom $i$ istoricheskom aspektakh: Materialy V Mezhdunarodnoj konferentsii po sravnitel'no-istoricheskomu jazykoznaniju (Moskva, 31 janvarja - 2 fevralja 2006 g.). Moskva: Izdatel'stvo Moskovskogo universiteta, 9-44.

Bazzarelli, Eridano 1976. O perevode “Bozhestvennoj Komedii” Lozinskim: Sistema ehkvivalentov. Tr. by S. Ja. Somovaja. In Bushmin, Aleksei Sergeevich (ed.), Sravnitel'noe izuchenie literatur: Sbornik statej k 80-letiju akademika M. P. Alekseeva. Leningrad: Nauka, 315-323.

Belyi, Andrei 1910. Simvolizm: Kniga statej. Moskva: Musaget.

Belyi, Andrei 1926. Moskva pod udarom: Vtoraja chast' romana "Moskva". Moskva: Krug.

Belyi, Andrei 1932. Maski. Moskva: Gosudarstvennoe izdatel'stvo khudozhestvennoj literatury. 
Bernshtein, Sergei Ignat'evich 1929. Opyt analiza "slovesnoj instrumentovki” (I-aja strofa stikhotvorenija Tjutcheva "Sumerki"). In: Poetika: Vremennik Otdela slovesnykh iskusstv Gosudarstvennogo instituta istorii iskusstv 5. Leningrad: Academia, 156-192.

Bobrov, Sergei Pavlovich. 1922. Zaimstvovanija i vlijanija. In: Pechat' i revoljutsija 8, 72-92.

Brik, Osip Maksimovich 1917. Zvukovye povtory (Analiz zvukovoj struktury sticha). In: Sborniki po teorii poeticheskogo jazyka 2. Petrograd: Tipografija Z. Sokolinskogo, 24-62.

Brik, Osip Maksimovich 1927. Ritm i sintaksis. In: Novyj Lef 3, 15-20; 4, 23-29; 5, 32-37; 6, 33-39.

Briusov, Valery Yakovlevich 1900. Po povodu novogo izdanija sochinenij F. I. Tjutcheva. In: Russkij Arkhiv 3, 405-420.

Briusov, Valery Yakovlevich 1904. René Ghil. In: Vesy 12, 12-31.

Briusov, Valery Yakovlevich 1911. Ot perevodchika. In: Verlaine, Paul. Sobranie stikhov. V perevode Valerija Briusova. Moskva: Skorpion, 7-13.

Catford, John Cunnison 1965. A Linguistic Theory of Translation: An Essay in Applied Linguistics (Languages and Language Learning 8). Oxford: Oxford University Press.

Chomsky, Noam 2006. Language and Mind. Third edition. New York: Cambridge University Press.

Červenka, Miroslav 1993. Literární artefakt. In: Kubínová, Marie (ed.), Kapitoly z teorie literárního díla. Praha: Karolinum, 98-137.

Červenka, Miroslav 2002. Hlásková instrumentace. In: Červenka, Miroslav; Jankovič, Milan; Kubínová, Marie; Langerová, Marie. Pohledy zblizka: zvuk, význam, obraz. Poetika literárního díla 20. století. Praha: Torst, 9-54.

Dauzat, Albert 1922. La géographie linguistique. Paris: Flammarion.

Dauzat, Albert 1927. Les patois: Évolution - classification: Étude avec 7 cartes. Paris: Delagrave.

Dmitriev, Pavel Viacheslavovich 1996. Dva soneta Petrarki v perevode M. Kuzmina. In: Novoe literaturnoe obozrenie 18, 222-224.

Doubrovkine, Roman (ed.) 2005. Ghil, René; Briusov, Valery Yakovlevich. Perepiska / Correspondance, 1904-1915. Sankt-Peterburg: Akademivheskij proekt. 
Ďurišin, Dionýz 1976. Perevod kak osobaja forma mezhliteraturnoj retseptsii. In: Bushmin, Alexey S. (ed.), Sravnitel'noe izuchenie literatur: Sbornik statej k 80-letiju akademika M. P. Alekseeva. Leningrad: Nauka, 493-498.

Ďurišin, Dionýz 1979. Teorija sravnitel’nogo izuchenija literatury. Avtorizovannyj perevod so slovatskogo I. A. Bogdanovoj. Moskva: Progress.

Eichstädt, Hildegard 1970. Žukovskij als Übersetzer: Drei Studien zu Übersetzungen V. A. Žukovskijs aus dem Deutschen und Französischen (Forum Slavicum 29). München: Wilhelm Fink.

Eikhenbaum, Boris Mikhailovich 1922. Melodika russkogo liricheskogo stikha. Peterburg: Opojaz.

Eikhenbaum, Boris Mikhailovich 1924 [1920]. O zvukakh v stikhe. In: Eikhenbaum, Boris Mikhailovich. Skvoz' literaturu: Sbornik statej (Voprosy poetiki 4). Leningrad: Academia, 201-208.

Eikhenbaum, Boris Mikhailovich 1924 [1921]. Melodika stikha. In: Eikhenbaum, Boris Mikhailovich. Skvoz' literaturu: Sbornik statej (Voprosy poetiki 4). Leningrad: Academia, 209-214.

Eikhenbaum, Boris Mikhailovich 1927 [1925]. Teorija "formal'nogo metoda" In: Eikhenbaum, Boris Mikhailovich. Literatura: Teorija. Kritika. Polemika. Leningrad: Priboj, 116-148.

Eikhenbaum, Boris Mikhailovich 1987 [1918]. O khudozhestvennom slove. In: Eikhenbaum, Boris Mikhailovich. O literature: Raboty raznykh let. Ed. by Chudakov, Aleksandr Pavlovich; Chudakova, Marietta Omarovna; Eikhenbaum, Ol'ga Borisovna; Toddes, Evgeny Abramovich. Moskva: Sovetskij pisatel', 331-343.

Etkind, Efim Grigor'evich 1973. Russkie poety-perevodchiki ot Trediakovskogo do Pushkina. Leningrad: Nauka.

Etkind, Efim Grigor'evich 1994. Vjacheslav Ivanov i voprosy poetiki: 1920-e gody. In: Cahiers du monde russe 35(1/2), 141-154.

Eoyang, Eugene Chen 2003. "Borrowed Plumage": Polemical Essays on Translation. Amsterdam; New York: Rodopi.

Erlich, Victor 1965. Russian Formalism: History - Doctrine (Slavistic Printings and Reprintings 4). Second revised edition. The Hague: Mouton \& Co.

Fedorov, Andrei Venediktovich 1928. Zvukovaja forma stikhotvornogo perevoda (Voprosy metriki i fonetiki). In: Poetika: Vremennik Otdela slovesnykh iskusstv Gosudarstvennogo instituta istorii iskusstv 4. Leningrad: Academia, 45-69. 
Fedorov, Andrei Venediktovich 1929. Russkij Gejne (40-ye - 60-ye gody) [1927]. Eikhenbaum, Boris Mikhailovich; Tynianov, Yuri Nikolaevich (ed., with introduction), Russkaja poezija XIX veka: Sbornik statej (Voprosy poetiki 13). Leningrad: Academia, 248-298.

Fedorov, Andrei Venediktovich 1983 [1974]. Fragmenty vospominanij. In: Kaverin, Veniamin Aleksandrovich (ed.), Vospominanija o Ju. Tynjanove: portrety i vstrechi. Moskva: Sovetskij pisatel', 85-108.

Fet, Afanasy Afanas'evich 1971. Vechernie ogni. Ed. by Blagoy, Dmitry Dmitrievich; Sokolova, Marija Aleksandrovna. Moskva: Nauka.

Fisher, Vladimir Mikhailov ich 1915. [Review of]: Petrarka. "Avtobiografija. Ispoved'. Sonety”. (Tr. by M. Gershenzon and Viach. Ivanov.) Moskva: M. i S. Sabashnikovy, 1915. In: Golos Minuvshego 15, 270-274.

Forster, Leonard 1970. The Poet's Tongues: Multilingualism in Literature. Cambridge: Cambridge University Press.

Gasparov, Mikhail Leonovich 1974. Sovremennyj russkij stikh: Metrika i ritmika. Moskva: Nauka.

Gasparov, Mikhail Leonovich 2001. Kommentarii. In: Mandel'shtam, Osip Emil'evich. Stikhotvorenija. Proza. Moskva: AST; Khar'kov, Folio, 604-710.

Gasparov, Mikhail Leonovich 2002. 319 sonet Petrarki v perevode O. Mandel'shtama: Istorija teksta i kriterii stilja. In: Andreev, Mikhail Leonidovich; Gurevich, Aron Yakovlevich; Shumilova, Elena Petrovna (eds.), Chelovek - Kul'tura - Istorija: V chest' semidesjatiletija L. M. Batkina. Moskva: RGGU, 323-337.

Gasparov, Mikhail Leonovich 2006. Semen Kirsanov, znamenosets sovetskogo formalizma. In: Kirsanov, Semen. Stikhotvorenija i poemy. Sankt-Peterburg: Akademicheskij proekt, 5-18.

Genette, Gérard 1997 [1982]. Palimpsests: Literature in the Second Degree. Tr. by Channa Newman and Claude Doubinsky. (Stages 8). Lincoln; London: University of Nebraska Press.

Gottzmann, Carola L.; Hörner Petra 2007. Lexikon der deutschsprachigen Literatur des Baltikums und St. Petersburgs: Vom Mittelalter bis zur Gegenwart. Bd. 1. Berlin; New York: Walter de Gruyter.

Grigor'ev, Viktor Petrovich 1979. Poetika slova: Na materiale russkoj sovetskoj poezii. Moskva: Nauka. 
Gugnin, Aleksandr Aleksandrovich 1985. [Kommentarii k perevodam V. A. Zhukovskogo] iz nemetskoj poezii. In Gugnin, Aleksandr Aleksandrovich (ed.), Zarubezhnaja poezija v perevodakh V. A. Zhukovskogo v 2 tomakh. T. 2. Moskva: Raduga, 576-596.

Harvey, Keith 1998. Compensation. In: Baker, Mona (ed.), Routledge Encyclopedia of Translation Studies. London; New York: Routledge, 37-40.

Hooley, Daniel M. 1988. The Classics in Paraphrase: Ezra Pound and Modern Translators of Latin Poetry. Selinsgrove, Pa: Susquehanna University Press; London and Toronto: Associated University Press.

Iliushin, Aleksandr Anatol'evich 1990. Dante i Petrarka v interpretatsii Mandel'shtama. In: Lasunsky, Oleg Grigor'evich (ed.), Zhizn' i tvorchestvo O. E. Mandel'shtama: Vospominanija. Materialy k biografii. "Novye stikhi”. Kommentarii. Issledovanija. Voronezh: Izdatel'stvo Voronezhskogo universiteta, 367-382.

Iliushin, Aleksandr Anatol'evich 2004. Russkoe stichoslozhenie. Second revised edition. Moskva: Vysshaja shkola.

Ivanov, Viacheslav Ivanovich 1930 [1925]. K probleme zvukoobraza u Pushkina. In: Tsjavlovsky, Mstislav Aliksandrovich (ed.), Moskovskij pushkinist 2. Moskva: Federatsija, 94-105.

Jakobson, Roman 1979. Retrospect. In: Jakobson, Roman. Selected Writings. Vol. 5: On Verse, Its Masters and Explorers. The Hague; Paris: Mouton, 569-601.

Jakobson, Roman; Pomorska, Krystyna 1985. Dialogue on time in language and literature. In: Jakobson, Roman. Verbal Art, Verbal Sign, Verbal Time. Ed. by Pomorska, Krystyna; Rudy, Stephen. Minneapolis: University of Minnesota Press, $11-24$.

Kahlenborn, Ulrike 1985. Goethes Lyrik in russischer Übersetzung: V. A. Žukovskij und F. I. Tjutčev als bedeutendste Goethe-Übersetzer der russischen Romantik (Slavistische Beiträge 185). München: Otto Sagner.

Kaplinsky, Vasily Yakovlevich 1915. Zhukovskij, kak perevodchik ballad. In: Zhurnal Ministerstva Narodnogo Prosveshchenija. Novaja serija 55(1), Otdelenie nauk, 1-25.

Katz, Michael R. 1976. The Literary Ballad in Early Nineteenth-Century Russian Literature. Oxford: Oxford University Press.

Kerndl, Alfred 1956. Studien über Heine in Rußland. In: Zeitschrift für slavische Philologie 24(1), 91-155; 24(2), 284-337.

Kiparsky, Paul 1977. The Rhythmic structure of English verse. In: Linguistic Inquiry 8(2), 189-247. 
Kolarov, Radosvet 1983. Zvuk i smisăl: Nabljudenija nad fonichnata organizatsija na chudozhestvenata proza. Sofija: Izdatelstvo na Bălgarskata akademija na naukite.

Kotomin, Mikhail Anatol'evich 2007. Pokrovsky Ivan Gavrilovich. In: Russkie pisateli: Biograficheskij slovar'. T. 5. Moskva: Nauchnoe izdatel'stvo “Bol'shaia rossijskaja entsiklopedija", 25-26.

Kviatkovsky, Aleksandr Pavlovich 1966. Poeticheskij slovar'. Moskva: Sovetskaja entsiklopedija.

Lebedeva, Ol'ga Borisovna 2008. Kubok: [A commentary]. In: Zhukovsky, Vasily Andreevich. Polnoe sobranie sochinenij i pisem v 20 tomakh. T. 5: Ballady. Moskva: Jazyki russkoj kul'tury, 394-400.

Lefevere, André 1975. Translating poetry: Seven Strategies and a Blueprint (Approaches to Translation Studies 3). Assen; Amsterdam: Van Gorcum.

Levin, Yuri Davidovich 1963. Ob istoricheskoj evoljutsii printsipov perevoda (K istorii perevodcheskoj mysli v Rossii). In: Alekseev, Mikhail Pavlovich (ed.), Meždunarodnye svjazi russkoj literatury. Moskva; Leningrad: Izdatel'stvo Akademii nauk SSSR, 5-63.

Levin, Yuri Davidovich 1972. O russkom poeticheskom perevode v epokhu romantizma. In: Alekseev, Mikhail Pavlovich (ed.), Rannie romanticheskie vejanija: Iz istorii mezhdunarodnykh svjazej russkoj literatury. Leningrad: Nauka, 222-284.

Levin, Yuri Davidovich 1985. Russkie perevodchiki XIX veka i razvitie khudozhestvennogo perevoda. Leningrad: Nauka.

Levinton, Georgy Akhillovich 1979. Poeticheskij bilingvizm i mezh"jazykovye vlijanija (Jazyk kak podtekst). In: Vtorichnye modelirujushchie sistemy. Tartu: Tartuskij gosudarstvennyj universitet, 30-33.

Levinton, Georgy Akhillovich 1986. Zametki k perevodcheskoj tekhnike Lomonosova. In: M. V. Lomonosov i russkaja kul'tura: Tezisy dokladov konferentsii, posvjashchennoj 275-letiju so dnja rozhdenija M. V. Lomonosova (28-29 nojabrja 1986 g.). Tartu: Tartuskij gosudarstvennyj universitet, 17-21.

Lipkin, Semen 1991. Ugl', pylajushchij ognem: Zarisovki i soobrazhenija (Biblioteka "Ogonek" 4), Moskva: Zhurnal "Ogonek".

Lotman, Juri [Jurij, Yuri Mikhailovich] 1976. Analysis of the Poetic Text. Tr. by D. Barton Johnson. Ann Arbor, Mich.: Ardis.

Lotman, Juri [Jurij, Yuri Mikhailovich] 1977. The Structure of the Artistic Text. Tr. by Gail Lenhoff and Ronald Vroon. (Michigan Slavic Contributions 7). Ann Arbor, Mich.: The University of Michigan. Department of Slavic Languages and Literatures. 
Lotman, Mihhail 2009. “Izjumu da sin'ki...” (Perevod i sdvig: Iz marginalij k obshchej teorii perevoda). Paper presented at the International Conference "The Borderline Phenomena in Culture" held in the framework of the First Annual Juri Lotman Days at Tallinn University (5-7 June 2009).

Mandelker, Amy 1983. Russian Formalism and the objective analysis of sound. In: The Slavic and East European Journal 27(3), 327-338.

Mandelshtam [Mandelstam], Osip 1979. The Complete Critical Prose and Letters. Tr. by Jane Gary Harris and Constance Link. Ann Arbor: Ardis.

Mandelshtam [Mandel'shtam], Osip Emil'evich 1990. Sochinenija. T. 1. Moskva: Khudozhestvennaja literatura.

Mandelstam, Nadezha Yakovlevna 1997. Zametki N. Ja. Mandel'shtam na poljakh amerikanskogo "Sobranija sochinenij" Mandel'sgtama. Ed. by Levina, Tatiana Mikhailovna; Nikitaev, Aleksandr Tikhonovich. In: Philologica 4(8/10), 169-199.

Matthisson, [Friedrich von] 1789. Elysium. In: Voß, I. H. [Johann Heinrich] (ed.), Musen Almanach für 1789. Hamburg: bey Carl Ernst Bohn, 106-108.

Mayakovsky, Vladimir 1975 [1926]. How to make verse. Tr. by Valentina Coe. In: Proffer, Carl (ed.) Modern Russian Poets on Poetry. Ann Arbor, Mich.: Ardis, 103-145.

Mukařovský, Jan 1976 [1940]. On Poetic Language. Tr. and ed. by John Burbank and Peter Steiner. Lisse: The Peter de Ridder Press.

Mukařovský, Jan 1978 [1934]. Art as a semiotic fact. In: Mukařovský, Jan. Structure Sign and Function: Selected Essays. Tr. and ed. by John Burbank and Peter Steiner. New Haven, CT: Yale University Press, 82-88.

Mureddu, Donata 1980. Mandel'štam and Petrarch. In: Scando-Slavica 26, 53-84.

Nelson Jr., Lowry 1986. Translatio Lauri: Ivanov's translation of Petrarch. In: Jackson, Robert Louis; Nelson Jr., Lowry (eds.), Vyacheslav Ivanov: Poet, Critic and Philosopher (Yale Russian and East European Publications 8). New Haven: Yale Center for International and Area Studies, 162-189.

Nida, Eugene Albert 1964. Toward a Science of Translating: With Special Reference to Principles and Procedures Involved in Bible Translating. Leiden: E. J. Brill.

Pilshchikov, Igor Alekseevich 1991. Problemy fonologii i prosodii perevodnogo teksta: K kharakteristike perevodcheskoj tekhniki V. A. Zhukovskogo. In: Altshuller, Mark (ed.), Graduate Essays on Slavic Languages and Literatures 4. Pittsburgh, Pa: The University of Pittsburgh. Department of Slavic Languages and Literatures, 19-29. 
Pilshchikov, Igor Alekseevich 2010. Petrarca nelle traduzioni dei poeti russi dell'età d’oro e dell'età d'argento. Tr. by Bianca Sulpasso. In: Russica Romana 17, 89-114.

Pilshchikov, Igor Alekseevich 2012. “Zvuki ital'janskie!”: O fonostilistike russkikh perevodov iz Petrarki. In: Carpi, Guido; Fleishman, Lazar; Sulpasso, Bianca (eds.), Venok: Studia slavica Stefano Garzonio sexagenario oblata. In Honor of Stefano Garzonio (Stanford Slavic Studies 40), Stanford: Stanford University. The Department of Slavic Languages and Literatures. Part I, 141-154.

Pilshchikov, Igor Alekseevich 2015. Traditsii "russkogo petrarkizma" i sonety Petrarki v perevode M. Kuzmina. In: Dmitriev, Pavel Vjacheslavovich; Lavrov, Aleksandr Vasil'evich (eds.), Mikhail Kuzmin: Literaturnaja sud'ba i khudozhestvennaja sreda. Sankt-Peterburg: Renome, 139-157.

Plungian, Vladimir Aleksandrovich 2013. K metrike mandel'shtamovskikh perelozhenij Petrarki. In: Fateeva, Natalia Aleksandrovna (ed.), Dialog kul'tur: "Ital'janskij tekst" v russkoj literature i "russkij tekst" v ital'janskoj literature: Materialy mezhdunarodnoj nauchnoj konferencii (Institut russkogo jazyka im. V. V. Vinogradova RAN, 9-11 ijunja 2011 g.). Moskva: Infotekh, 34-44.

Pokrovsky, Ivan Gavrilovich 1820. Vodolaz: Ballada (Iz Schillera). In: Syn otechestva 62(21), 83-89.

Polevoy, Nikolai Alekseevich 1839. Ocherki russkoj literatury. Chast' 1. SanktPeterburg: Tipografija Sakharova.

Polivanov, Evgeny Dmitrievich 1974 [1930]. The general phonetic principle of any poetic technique. In: Polivanov, Evgeny Dmitrievich. Selected works: Articles on General Linguistics (Janua linguarum. Series major 72). Tr. by Daniel Armstrong from the Russian edition: "Nauka”, 1968. The Hague; Paris: Mouton, 350-368.

Pomorska, Krystyna 1968. Russian Formalist Theory and its Poetic Ambiance (Slavistic Printings and Reprintings 82). The Hague; Paris: Mouton.

Pszczołowska, Lucylla 1977. Instrumentacja dźwiękowa (Poetyka: Zarys encyklopedyczny, section 3, vol. 2, part 2, issue 2). Wrocław; Warszawa; Kraków; Gdańsk: Zakład Narodowy im. Ossolińskich, Wydawnictwo Polskiej Akademii Nauk.

Pszczołowska, Lucylla 1982. Sound Texture: General Problems. In: Steiner, Peter; Červenka, Miroslav; Vroon, Ronald (eds.), The Structure of the Literary Process: Studies Dedicated to the Memory of Felix Vodička (Linguistic and Literary Studies in Eastern Europe 8). Amsterdam; Philadelphia, Pa: John Benjamins, 385-395.

Raffel, Burton 1988. The Art of Translating Poetry. University Park: Pennsylvania State University Press. 
Ronen, Omry 1973. Leksicheskij povtor, podtekst i smysl v poetike Osipa Mandel'shtama. In: Jakobson, Roman; Van Schooneveld, Cornelis H.; Worth, Dean S. (eds.), Slavic Poetics: Essays in honor of Kiril Taranovsky. The Hague; Paris: Mouton, 367-387.

Ronen, Omry 1997. Leksicheskie i ritmiko-sintaksicheskie povtorenija i "nekontroliruemyj podtekst”. In: Izvestija Rossijskoj akademii nauk. Serija literatury i jazyka 56(3), 40-44.

Ronen, Omry 2012. Podtekst. In: Zvezda 3, 230-238.

Schiller, Friedrich; Goethe, Johann Wolfgang 1845. Correspondence between Schiller and Goethe, 1794 to 1805. Vol. 1. Translated by George H. Calvert. New York; London: Wiley and Putnam.

Schiller, Friedrich; Goethe, Johann Wolfgang 1870. Briefwechsel zwischen Schiller und Goethe in den Jahren 1794 bis 1805. 3. Ausgabe. Bd. 1. Stuttgart: J. G. Cotta.

Segal, Dmitry Mikhailovich 1972. Osnovy fonologicheskoj statistiki (na materiale pol'skogo jazyka). Moskva: Nauka.

Semenko, Irina Mikhailovna 1970. Mandel'shtam - perevodchik Petrarki. In: Voprosy literatury 10, 153-169.

Semenenko, Aleksei 2007. Hamlet the Sign: Russian Translations of Hamlet and Literary Canon Formation (Acta Universitatis Stockholmiensis. Stockholm Studies in Russian Literature 39). Stockholm: Stockholms universitet.

Semenko, Irina Mikhailovna 1975. Zhizn’ i poezija Zhukovskogo. Moskva: Khudozhestvennaja literatura.

Semenko, Irina Mikhailovna 1976. Vasily Zhukovsky (TWAS 271). New York: Twayne.

Sharov, Nikolai V. 1922. Stikhotvorenija G. Gejne [H. Heine] v perevode F. I. Tjutcheva. In: Trudy Belorusskogo Gosudarstvennogo Universiteta v Minske 1, 139-147; 2/3, 97-113.

Shcherba, Lev Vladimirovich 1923. Opyty lingvisticheskogo tolkovanija stikhotvorenij:

I. "Vospominanie" Pushkina. In: Shcherba, Lev Vladimirovich (ed.), Russkaja rech' 1. Petrograd: Izdanie foneticheskogo instituta prakticheskogo izuchenija jazykov, 13-56.

Shengeli, Georgy Arkad'evich 1923. Traktat o russkom stikhe. T. 1: Organičeskaja metrika. Izdanie 2-e, pererabotannoe. Moskva; Petrograd: Gosudarstvennoe izdatel'stvo.

Shklovsky, Viktor Borisovich 1916. O poezii i “zaumnom” jazyke. In: Sborniki po teorii poeticheskogo jazyka 1. Petrograd: Tipografija Z. Sokolinskogo, 1-15. 
Shklovsky, Viktor Borisovich 1923. Literatura i kinematograf. Berlin: Russkoe universitetskoe izdatel'stvo.

Shtokmar, Mikhail Petrovich 1939. Fonika. In Literaturnaja entsiklopedija. T. 11. Moskva: Gosudarstvennoe izdatel'stvo "Khudozhestvennaja literatura”, col. 802-804. Signed: $M$. Sh.

Shveitser, Aleksandr Davidovich 1988. Teorija perevoda: status, problemy, aspekty. Moskva: Nauka.

Silman [Sil'man], Tamara Isaakovna 1969. Podtekst kak lingvisticheskoe javlenie. in: Nauchnye doklady vysshej shkoly. Filologicheskie nauki 1/49, 84-90.

Skirmantas, Petras P. 1984. Fonika stikhotvorenij S. Néris (rannij period): Avtoreferat dissertatsii na soiskanie uchenoj stepeni kandidata filologicheskikh nauk. Vilnius: Vil'njusskij gosudarstvennyj universitet im. V. Kapsukasa.

Smith, Frank 1978. Understanding Reading: A Psycholinguistic Analysis of Reading and Learning to Read. Second edition. New York; Chicago; San Francisco [etc.]: Holt, Rinehart and Winston.

Steiner, George 1998 [1975]. After Babel: Aspects of Language and Translation. Third edition. Oxford: Oxford University Press.

Tammi, Pekka 1991. Text, subtext, intertext: On applying Taranovsky's analytic method (with examples from Finnish poetry). In: Semiotica 87(3/4), 315-347.

Taranovsky, Kiril [Kirill Fedorovich] 1965. The sound texture of Russian verse in the light of phonemic distinctive features. In: International Journal of Slavic Linguistic and Poetics 9, 114-124.

Taranovsky, Kirill Fedorovich 1966. Zvukopis’ v “Severovostoke” M. Voloshina. In: Gerhardt, Dietrich; Weintraub, Wiktor; Zum Winkel, Hans-Jürgen (eds.), Orbis scriptus: Dmitrij Tschiževskij zum 70. Geburtstag. München: Wilhelm Fink, 835-840.

Tesnière, Lucien 1965. Éléments de syntaxe structurale. Deuxième édition revue et corrigé. Paris: Klincksieck.

Testelets, Jakov Georgievich 2001. Vvedenie v obshchij sintaksis. Moskva: RGGU.

Timofeev, Leonid Ivanovich 1958. Ocherki teorii i istorii russkogo stikha. Moskva: Gosudarstvennoe izdatel'stvo khudozhestvennoj literatury.

Tiutchev, Fedor Ivanovich 1966. Lirika. T. 2. Ed. by Pigarev, Kirill Vasil'evich. Moskva: Nauka. 
Toury, Gideon 1990. From one signifier to another: modified phonetic transposition in word-formation and translation. In: Arntz, Reiner; Thome, Gisela (eds.), Übersetzungswissenschaft: Ergebnisse und Perspektiven: Festschrift Für Wolfram Wilss Zum 65. Geburtstag. Tübingen: G. Narr, 191-198.

Turgenev, Aleksandr Ivanovich 1872. Pis'ma Aleksandra Ivanovicha Turgeneva $k$ Nikolaju Ivanovichu Turgenevu. Leipzig: F. A. Brockhaus.

Tynianov, Yuri Nikolaevich 1924. Problema stikhotvornogo jazyka (Voprosy poetiki 5). Leningrad: Academia.

Tynianov, Yuri Nikolaevich 1929 [1922]. Oda kak oratorskij zhanr. In: Tynianov, Yuri Nikolaevich. Arkhaisty i novatory. Leningrad: Priboj, 48-86.

Tynianov, Yuri Nikolaevich 1977 [1921-1922]. O kompozitsii “Evgenija Onegina”. In: Tynianov, Yuri Nikolaevich. Poetika. Istorija literatury. Kino. Ed. by Chudakov, Aleksandr Pavlovich; Chudakova, Marietta Omarovna; Toddes, Evgeny Abramovich. Moskva: Nauka, 52-77.

Tynianov, Yuri Nikolaevich 1977 [1922]. Tjutchev i Gejne [Tiutchev and Heine]. In: Tynianov, Yuri Nikolaevich. Poetika. Istorija literatury. Kino. Moskva: Nauka, 385-393.

Vakhros, Igor' 1966/1967. O perevodakh Tjutcheva iz Gejne. In: Annuaire de l'Institut de Philologie et d'Histoire Orientales et Slaves. T. 17. Bruxelles: Université Libre de Bruxelles, 427-442.

Vatsuro, Vadim Erazmovich 1994. Lirika pushkinskoj pory: "Elegicheskaja shkola". Sankt-Peterburg: Nauka.

Vekshin, Georgy Viktorovich 2006. Ocherk fonostilistiki teksta: zvukovoj povtor v perspektive smysloobrazovanija. Moskva: MGUP.

Venclova, Tomas 1991. Vjacheslav Ivanov i Osip Mandel'shtam - perevodchiki Petrarki (na primere soneta CCCXI. In: Russkaja literatura 4, 192-200.

Venuti, Lawrence: 2008 [1995], The Translator's Invisibility: A history of Translation. Second edition. London; New York: Routledge.

Vitkovsky, Evgeny Vladimirovich 2004. Semen Kirsanov. In: Vek perevoda: Russkij poeticheskij perevod XX-XXI vekov. Published online 07.10.2004. URL: http://www. vekperevoda.com/1900/skirsanov.htm (accessed 30.04.2016).

Weinreich, Uriel 1953. Languages in Contact: Findings and Problems. With a Preface by André Martinet (Publications of the Linguistic Circle of New York 1). New York: Linguistic Circle of New York. 
Wellek, René; Warren, Austin 1963. Theory of Literature. Third revised edition. Harmondsworth: Peregrine Books.

Yakubinsky, Lev Petrovich 1916. O zvukach stikhotvornogo jazyka. In: Sborniki po teorii poeticheskogo jazyka 1. Petrograd: Tipografija Z. Sokolinskogo, 16-30.

Zhirmunsky, Viktor Maksimovich 1932. Gete [Goethe] v russkoj poezii. In: Literaturnoe nasledstvo 4/6. Moskva: Zhurnal'no-gazetnoe ob"edinenie, 505-650.

Zhirmunsky, Viktor Maksimovich 1937. Gete [Goethe] v russkoj literature. Leningrad: Gosudarstvennoe izdatel'stvo khudozhestvennoj literatury.

Zhukovsky, Vasily Andreevich 1813. Elizium. In: Vestnik Evropy 68(7/8), 201-203. Unsigned.

Zhukovsky, Vasily Andreevich 1815. Stikhotvorenija. Chast' 1. Sankt-Peterburg: V Meditsinskoj tipografii.

Zhukovsky, Vasily Andreevich 1818. Goethe. An den Mond; [Zhukovsky]. K mesjatsu: [Parallel texts]. In: Für wenige. Dlja nemnogikh 2, 28-33. Unsigned. 